University of Miami Law School

University of Miami School of Law Institutional Repository

2012

\title{
Whistleblowers and Rogues: An Urgent Call for an Affirmative Defense to Corporate Criminal Liability
}

Marcia Narine

University of Miami School of Law

Follow this and additional works at: https://repository.law.miami.edu/fac_articles

Part of the Business Organizations Law Commons

\section{Recommended Citation}

Marcia Narine, Whistleblowers and Rogues: An Urgent Call for an Affirmative Defense to Corporate Criminal Liability, 62 Cath. U. L. Rev. 41 (2012).

This Article is brought to you for free and open access by the Faculty and Deans at University of Miami School of Law Institutional Repository. It has been accepted for inclusion in Articles by an authorized administrator of University of Miami School of Law Institutional Repository. For more information, please contact library@law.miami.edu. 


\title{
WHISTLEBLOWERS AND ROGUES: AN URGENT CALL FOR AN AFFIRMATIVE DEFENSE TO CORPORATE CRIMINAL LIABILITY
}

\author{
Marcia Narine ${ }^{+}$
}

I. A BRIEF HISTORY OF CORPORATE CRIMINAL LIABILITY..............................51

A. The Effects of Respondeat Superior Liability on Corporate

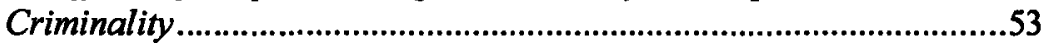

B. Alternative Theories of Liability ....................................................58

1. The Model Penal Code .................................................................58

2. The Collective Action Doctrine.....................................................59

II. THE DEPARTMENT OF JUSTICE'S ROLE IN IMPOSING

CORPORATE CRIMINAL LIABILITY .................................................60

A. DOJ Guidelines and Deferred Prosecution Agreements......................60

B. An Overview of the Role of Compliance Programs and the Sentencing Guidelines..............................................................66

III. A PILOT FOR AN AFFIRMATIVE DEFENSE .............................................72

A. The Foreign Corrupt Practices Act ..................................................72

B. International Enforcement and Defenses ............................................75

IV. PARAMETERS FOR A NEW AFFIRMATIVE DEFENSE .................................79

A. A Title VII Analogy ..............................................................................79

B. Elements of the Enhanced Compliance Program Required to Prevail

V. CONCLUSION

Many weeds have grown on the acre of jurisprudence[,] which has been allotted to the criminal law. Among these weeds is a hybrid of vicarious liability, absolute liability, an inkling of mens rea-though a rather degenerated mens rea-, a few genes from tort law and a few from the law of business associations. The weed is called

\footnotetext{
+ Visiting Assistant Professor of Law, University of Missouri-Kansas City School of Law. My views are informed by personal experience developing compliance programs, meeting with the Securities and Exchange Commission on the effectiveness of these programs, working with advocacy groups and legislators on draft legislation related to Dodd-Frank whistleblower legislation, and testifying before a Congressional committee on the unintended consequences of that legislation on compliance programs. Thanks to Jennifer Arlen, Debbie Brooks, June Carbone, Barbara Glesner Fines, Mike Koehler, Fred Krebs, Nancy Levit, Lucinda Low, Joseph E. Murphy, Ellen Podgor, and Amar Sarwal for their insightful comments. I would also like to thank my research assistants LaTonya Brown, Cecilia Martin, and Kelly J. Thompson.
} 
corporate criminal liability . . . . Nobody bred it, nobody cultivated it, nobody planted it. It just grew. ${ }^{1}$

On July 21, 2010, after the 2008 financial and housing market collapse, President Barack Obama signed the Dodd-Frank Wall Street Reform and Consumer Protection Act (Dodd-Frank) into law. ${ }^{2}$ Like its predecessor, Sarbanes-Oxley, which was less than a decade old at the time of Dodd-Frank's inception, ${ }^{3}$ some scholars have labeled Dodd-Frank the latest in a round of "quack corporate governance." 4 Under this theory, the Dodd-Frank legislation passed too quickly in response to a crisis and therefore will fail to prevent the next financial crisis. ${ }^{5}$

The recent meltdown of the financial markets as well as other corporate scandals have caused the public to distrust corporations and consequently urge Congress to pass new legislation. ${ }^{6}$ Congress, in its zeal for "reform," missed the opportunity that the 2008 crisis created to focus on creating legislation that eliminates the disincentives of compliance. ${ }^{7}$ However, corporate compliance programs may bring to light or even prevent illegal or unethical business practices. $^{8}$ In their efforts to prevent and prohibit illegal conduct, corporations must comply and contend with several statutory frameworks: (1) the Dodd-Frank whistleblower legislation, which rewards tipsters even if they bypass internal compliance programs; ${ }^{9}$ (2) the 2010 U.K. Bribery Act, which

1. Gerhard O.W. Mueller, Mens Rea and the Corporation: A Study of the Model Penal Code Position on Corporate Criminal Liability, 19 U. PITT. L. REV. 21, 21, 23 (1957) (emphasis omitted) (arguing that the law of corporate criminal liability "has proceeded without rationale whatsoever").

2. Dodd-Frank Wall Street Reform and Consumer Protection Act, Pub. L. No. 111-203, 124 Stat. 1376 (2010) (to be codified in scattered sections of the United States Code). The Act includes corporate governance and executive compensation reforms, new rules for credit rating agencies, new registration requirements for hedge fund and private equity fund advisers, heightened regulation of over-the-counter derivatives and asset-backed securities, and significantly increased regulation of banks and other financial institutions. Id.

3. Sarbanes-Oxley Act of 2002, Pub. L. No. 107-204, 116 Stat. 745 (codified at 15 U.S.C. $\$ \$ 7201-7266$ (2006)).

4. E.g., Stephen M. Bainbridge, Dodd-Frank: Quack Federal Corporate Governance Round II, 95 MINN. L. REV. 1779, 1780 (2011) (quoting Roberta Romano, The Sarbanes-Oxley Act and the Making of Quack Corporate Governance, 114 YALE L.J. 1521 (2005)) (internal quotation marks omitted).

5. See id. at 1786-87, 1819 (discussing the consequences of "quack" legislation).

6. See id. at 1785-86 (noting the public scrutiny of corporate transactions in the wake of scandals).

7. See text accompanying notes 189-94.

8. See U.S. SENTENCING GuIDELINES MANUAL $§ 8 B 2.1$ (a) (2004) (describing an effective compliance program).

9. Securities Exchange Act of 1934, Pub. L. No. 73-291, $\$ 21 \mathrm{~F}, 48$ Stat. 881 (codified as amended at 15 U.S.C. $\$ 78 \mathrm{u}-6$ (Supp. IV 2010)) (establishing that whistleblowers who provide original information to the SEC related to securities fraud or violations of the Foreign Corrupt Practices Act are able to receive ten to thirty percent of the total recovery in any action in which 
imposes strict liability on companies doing business in the United Kingdom; ${ }^{10}$ and (3) the Sentencing Reform Act and Federal Sentencing Guidelines (Guidelines), which are used to sentence corporate defendants. ${ }^{11}$ In light of this changing regulatory landscape, it is necessary to eliminate the current disincentives in order to optimize compliance.

When Congress mandated a review of the Guidelines after the passage of Sarbanes-Oxley, ${ }^{12}$ it should have called for a similar review after the passage of Dodd-Frank. Notwithstanding the lack of review, legislators must now provide an affirmative defense for effective compliance programs that have been audited by an independent third party or pre-certified by an appropriate government agency. ${ }^{13}$ This defense would set a higher standard for both companies and the government, allowing both the private and public sectors to allocate their resources productively. ${ }^{14}$

A basic tenet of criminal law is the requirement of mens rea or, in other words, intent. ${ }^{15}$ Judges then sentence individual defendants based upon a number of aggravating and mitigating factors that are typically within the defendant's control. However, the law treats corporations differently than individual defendants. ${ }^{16}$ Criminal law assumes that corporations have mens rea, even though they function through their employees, who may act for or in contravention with the corporation's interests. ${ }^{17}$ In many instances, corporate management either condones an environment of criminality or chooses to be willfully blind to unethical or illegal behavior committed by employees and

the Commission levies sanctions in excess of one million dollars). The legislation also contains an anti-retaliation clause that expands the reach of Sarbanes-Oxley. Id.

10. Bribery Act, 2010, c. $23, \S 7$ (U.K.).

11. Sentencing Reform Act of 1984, Pub. L. No. 98-473, $\S \S 211-39$, 98 Stat. 1937, $1987-2040$ (codified as amended in scattered sections of 18 U.S.C. and 28 U.S.C. $\$ \S 991-998$ (2006)); U.S. SENIENCING GUIDELINES MANUAL § 1A1.1. Firms model their compliance programs on standards set forth in the Sentencing Guidelines and generally include a compliance or ethics officer and an anonymous, confidential reporting system such as a hotline. See U.S. SENTENCING GUIDELINES MANUAL § 8C2.5(f).

12. Ethics Res. Ctr., Fed. Sentencing Guidelines for Orgs., The Federal SENTENCING GUIDELINES FOR ORGANIZATIONS AT TWENTY YEARS: A CALL TO ACTION FOR

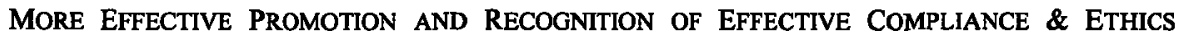
PROGRAMS, at A-6 (2012) [hereinafter ERC REPORT].

13. See infra Part IV.B.

14. See infra Part IV.

15. Mens rea is defined as "[ $t]$ he state of mind that the prosecution, to secure a conviction, must prove that a defendant had when committing a crime." BLACK's LAW DICTIONARY 1075 (9th ed. 2009).

16. See John Hasnas, The Centenary of a Mistake: One Hundred Years of Corporate Criminal Liability, 46 AM. CRIM. L. REV. 1329, 1338 (2009) (describing corporate criminal liability and arguing for its abolition).

17. See id. at 1337-38 (explaining that "the employee's actions and mental states will be attributed to the corporation despite being in violation of corporate policy and explicit instructions to the contrary" (citing United States v. Hilton Hotels Corp., 467 F.2d 1000, 1007 (9th Cir. 1972))). 
their agents. ${ }^{18}$ In others, companies-specifically those operating in other countries-have agents, vendors, and suppliers that skirt local law in order to meet their obligations to the client company. ${ }^{19}$ In these cases, although the corporation may not order the illegal behavior, management knows or should know that its suppliers, agents, or vendors cannot meet their goals without violating the law. ${ }^{20}$ In still other instances, rogue employees commit crimes without management's approval or knowledge. ${ }^{21}$ Employees do this to enhance their own promotion or bonus opportunities, or, in the case of insider trading or embezzlement, to enrich themselves. ${ }^{22}$

There is a subtle distinction between each of the aforementioned scenarios. It is unlikely that a corporation would approve of employee embezzlement or other crimes that directly harm itself. ${ }^{23}$ However, bribing a foreign individual may benefit not only the company by bringing in new business but also the employee who may receive a promotion or bonus for securing the new business. ${ }^{24}$ Regardless of the situation, if illegal employee behavior comes to management's attention, the company must disavow the conduct. ${ }^{25}$ In the embezzlement scenario, the company has an incentive to find out, but in the bribery case, it does not because it would then be forced to act on the knowledge acquired. ${ }^{26}$

Although corporate culture may either condone or condemn illegal acts, the treatment of firms, with regard to liability, remains the same. For example, a responsible company with a strong compliance program, an actively engaged

18. Jayne W. Barnard, Reintegrative Shaming in Corporate Sentencing, 72 S. CAL. L. REV. 959, 976 (1999).

19. See, e.g., Charles Duhigg \& David Barboza, In China, Human Costs Are Built Into an iPad, N.Y. TIMES, Jan. 26, 2012, at Al (providing examples of employees circumventing legal obligations in order to satisfy their corporations).

20. Id. (highlighting numerous violations of trade laws and Apple's Code of Conduct by Apple suppliers that Apple should have discovered). For years, Apple refused to publicly name its Chinese manufacturers, arguing that the information constituted a trade secret, but, after negative publicity, Apple released the names of its suppliers including one supplier that had an alarming number of suicides among its workers. Id. In 2011, the Fair Labor Association conducted an investigation into Foxconn, Apple's largest Chinese supplier. FAIR LABOR ASs'N, FOXCONN INVESTIGATION REPORT 1, 3 (2012), available at http://www.fairlabor.org/sites/default/files/documents/reports/foxconn-investigation-report.pdf.

21. See Hasnas, supra note 16, at 1337-38 (explaining that corporations are still responsible for employees' actions that go against express orders).

22. See, e.g., Michael P. Dooley, Enforcement of Insider Trading Restrictions, 66 VA. L. REV. 1, 5-6 (1980) (explaining insider trading and how employees benefit from it).

23. See INST. INTERNAL AUdiTORS ET AL., MANAGING THE BUSINESS RISK OF FRAUD: A PRACTICAL GUIDE 5 (2008) (explaining the many negative effects of employee fraud on a corporation and various steps that have been taken to try and mitigate these harms).

24. See, e.g., FCPA Winter Review 2010, Miller \& ChEvalier (Jan. 12, 2010), http://www.millerchevalier.com/Publications/MillerChevalierPublications?find=23807.

25. U.S. SENTENCING GUIDELINES MANUAL § 8B.2.1(B)(7) (2004).

26. See, e.g., FCPA Winter Review 2010, supra note 24 (providing examples of how bribing a foreign official has benefitted both individuals and companies). 
board of directors, a credible hotline or reporting system with anti-retaliation protection, and a vigorous auditing and monitoring function still has the same level of culpability as the company with the paper compliance program, perfunctory training, and a head-in-the-sand management team. ${ }^{27}$ The key to greater deterrence of illegal behavior is to increase incentives for investigating and decreasing a corporation's ability to claim a lack of knowledge of the illegal conduct. ${ }^{28}$ The current system discourages this inquiry. ${ }^{29}$ Whether or not management knows of or encourages the behavior, firms are subject to significant financial penalties and criminal liability for their employees' actions, even if the employees disobey articulated and enforced standards or if the company self-reports the conduct to the government. ${ }^{30}$ This leads to a system in which corporate management has little incentive to closely monitor their employees' behavior or invest significant sums in preventive compliance systems. 31

Ironically, this means that companies receive the maximum benefit from compliance programs that appear to comply with the Guidelines but that do not actually detect or deter wrongful conduct. ${ }^{32}$ Existing law further skews the perverse effects of these incentives. ${ }^{33}$ A firm following the Guidelines still faces vicarious criminal liability for the acts of its employees regardless of the effectiveness of its compliance program. ${ }^{34}$ The only benefit of adhering to the Guidelines compliance program is a reduction in penalties. ${ }^{35}$

27. See Examining Enforcement of the Foreign Corrupt Practices Act: Hearing Before the Subcomm. on Crime and Drugs of the S. Comm. on the Judiciary, 111th Cong. 26 (2010) [hereinafter Senate FCPA] (statement of Greg Andres, Deputy Assistant Att'y Gen., Criminal Division, U.S. Department of Justice) (explaining that these types of factors may play a role in sentencing or prosecutorial decisions but not in the level of a company's culpability).

28. See Mike Koehler, Revisiting a Foreign Corrupt Practices Act Compliance Defense, 2012 WIS. L. REV. 609, 659 (2012) (concluding that compliance standards should be re-evaluated).

29. See Justin Blount \& Spencer Markel, The End of the Internal Compliance World as We Know It, or an Enhancement of the Effectiveness of Securities Law Enforcement? Bounty Hunting Under the Dodd-Frank Act's Whistleblower Provisions, 17 FORDHAM J. CORP. \& FIN. L., 1023, 1038-42 (2012) (discussing the "race to report" and how the current Dodd-Frank framework encourages "bypassing costly internal compliance programs and reporting securities law violations behind the company's back").

30. See Philip A. Wellner, Note, Effective Compliance Programs and Corporate Criminal Prosecutions, 27 CARDOZO L. REV. 497, 503-04 (2005) (explaining vicarious liability in the context of corporations and their employees' criminal acts).

31. See id. at 510-11 (discussing the disincentives of implementing compliance programs).

32. See id. at 498-99 (commenting that companies are implementing "less-than-ideal" compliance programs).

33. Id.

34. See Koehler, supra note 28, at 629 (quoting James R. Doty, Toward a Reg. FCPA: A Modest Proposal for Change in Administering the Foreign Corrupt Practices Act, 62 BUS. LAW. 1233, 1235 (2007)).

35. See, e.g., Deferred Prosecution Agreement at 5, United States v. Depuy, Inc., No. 11-CR-099 (D.D.C. Apr. 8, 2011) [hereinafter Johnson \& Johnson DPA], available at 
This disparity discourages firms from making optimal investments in training, auditing, and monitoring programs. ${ }^{36}$ In order to encourage greater detection and documentation of activities the company may otherwise prefer to ignore, the government must provide corporations with incentives. ${ }^{37}$ To do so, the government must also devise more effective ways to distinguish programs that force greater investigation and disclosure from those that are merely cosmetic. $^{38}$

Instead of finding a proactive solution to prevent corporate criminality following the 2008 crisis, Congress enacted the Dodd-Frank "bounty-hunter" law, partially in response to the Securities and Exchange Commission's (SEC) failure to deal appropriately with the whistleblower in the Bernard Madoff matter $^{39}$ and partially to encourage employees to report wrongdoing. ${ }^{40}$ Unfortunately, like other financial legislation passed after 2008, the Dodd-Frank whistleblower legislation also has flaws. ${ }^{41}$ Instead, Congress should have focused on incentives and penalties that would have a measurable effect on corporate behavior and on individuals within corporations to prevent the next financial crisis.

Contrary to its intent, the Dodd-Frank whistleblower legislation will not deter corporations from committing securities fraud or bribing government

http://www.justice.gov/criminal/fraud/fcpa/cases/depuy-inc/04-08-11depuy-dpa.pdf (noting that Johnson \& Johnson received a reduction in the culpability score for self-reporting). Prosecutors still required Johnson \& Johnson to reform its compliance programs. See id. at 7.

36. See Wellner, supra note 30, at 498-99 (noting that "[t]he law creates distorted incentives by offering corporations a sentence reduction for their compliance programs, which thus encourages corporations to implement less-than-ideal programs . . . [and] may lead corporations to expend resources in an inefficient manner, by funding compliance programs that are expensive to operate, undermining the desired result of deterring criminal activity within the corporation." (footnote omitted)). Wellner opposes affirmative defenses for corporate criminal liability and suggests removing the "effective compliance programs" standard from the Guidelines. Id. at 500; see also Kimberly D. Krawiec, Organizational Misconduct: Beyond the Principal-Agent Model, 32 FLA. ST. U. L. REV. 571, 572 (2005) (arguing that internal compliance systems encourage implementation of cosmetic programs that only reduce legal liability, not misconduct). This Article contends that compliance programs need to be strengthened and either audited by a third party or pre-certified by a governmental entity, and only then should a firm be able to avail itself of an affirmative defense.

37. See Wellner, supra note 30, at 514 (noting the need for better use of corporate resources).

38. See infra Part VI.B (arguing that one method for distinguishing between programs is to require compliance programs to be audited by an independent third party).

39. See Blount \& Markel, supra note 29, at1025 (describing the Madoff $\$ 65$ billion dollar Ponzi scheme as a reason for the new legislation).

40. See id. at 1026 (addressing the rationale behind the enactment of Dodd-Frank).

41. Marcia Narine, Missing the Mark and Wasting a Crisis: The Dodd-Frank Whistleblower Bounty Provision and a Call for an Affirmative Defense for Corporate Criminal Liability, CONGLOMERATE BLOG (Dec. 8, 2011), http://theconglomerate.org/2011/12/missing-the-mark -and-wasting-a-crisis-the-dodd-frank-whistleblower-bounty-provision-and-a-call-for-a.html. 
officials. $^{42}$ Although the legislation may achieve regulators' narrow goal of encouraging more people to bring information directly to the SEC, it will not satisfy the public's goal of preventing the next financial crisis because of its lack of deterrence. ${ }^{43}$ Furthermore, by offering a reward for information, even when whistleblowers bypass credible company compliance programs, the legislation provides a further disincentive for companies to make significant investments in these programs. ${ }^{44}$

This Article proposes a new framework to analyze the adequacy of an effective corporate compliance program that, in turn, could provide the basis for an affirmative defense. Under this proposed framework, companies faced with liability could proceed down one of two tracks. ${ }^{45}$ The first track is a complete defense, which would only succeed if the company obtained an independent certification of the program's effectiveness. ${ }^{46}$ A private or government entity would conduct the independent certification, free from the conflict of interests that plagued many of the auditors, rating agencies, and other gatekeepers during the 2008 financial crisis. ${ }^{47}$

A company with an optimal compliance program would likely not need to reach a court because the defense would be used at the earliest stage in negotiations. As a result, the government would decline to charge or prosecute at all, and there would be no fines or penalties attached. If, however, the government decided to bring charges against a company, the company could raise the defense.

Once in court, the accused company would provide evidence of how the compliance program operated in the case at issue, including when and whether the wrongdoers were trained, the kind of incentive plans that could have either led to or discouraged the behavior, and the types of auditing and monitoring programs that were in place to detect or deter the behavior. ${ }^{48}$ Courts or regulators would assess reasonableness by comparing the company's policies

42. Id.

43. See Legislative Proposals to Address the Negative Consequences of the Dodd-Frank Whistleblower Provisions: Hearing Before the Subcomm. on Capital Mkts. and Gov't Sponsored Enters. of the Comm. on Fin. Servs., 112th Cong. 6-9 (2011) [hereinafter Legislative Proposals Hearing] (testimony of Marcia Narine, witness on behalf of the U.S. Chamber of Commerce), available at http://financialservices.house.gov/Calendar/EventSingle.aspx?EventID=239790.

44. See id.

45. See infra notes 46-53.

46. See Richard S. Gruner \& Louis M. Brown, Organizational Justice: Recognizing and Rewarding the Good Citizen Corporation, 21 J. CORP. L. 731, 760-61 (1996) (describing the new standard as more rigorous than the current Guidelines).

47. See Editorial, Beyond the Raters, N.Y. TIMES, Dec. 15, 2011, at A38 (arguing that eliminating rating agencies as the official arbiters of financial stability will make the system more objective).

48. See Gruner \& Brown, supra note 46, at 763-64 (providing a basis for assessing a defendant organization's effort to avoid illegal employee behavior). 
and procedures to those of similarly situated firms. ${ }^{49}$ The burden would then shift to the government, which would have to rebut the presumption that the firm had an effective compliance program. ${ }^{50}$ Courts would then examine a number of factors, including and expanding on those used by prosecutors, sentencing judges, and other legal regimes around the world. A company's defense would be limited to instances in which employees committed misconduct contrary to law, policy, or management instructions, and where the company acted with diligence to prevent illegal behavior and had disclosed to the government when appropriate. ${ }^{51}$ The more senior the employee, the less likely the company would be able to use this defense. ${ }^{52}$

In the second track, companies that are charged with crimes and have compliance programs below the new standard would be required either to go to trial or to settle their case. This often occurs through deferred prosecution agreements (DPAs) and non-prosecution agreements (NPAs), which either

49. Developments in the Law-Corporate Crime: Regulating Corporate Behavior Through Criminal Sanctions, 92 HARV. L. REV. 1227, 1241-58 (1979) [hereinafter Developments in the Law] (allowing a rebuttable presumption to vicarious liability with a due diligence defense).

50. ANDREW WEISSMANN ET AL., REFORMING CORPORATE CRIMINAL Liability to PROMOTE RESPONSIBLE CORPORATE BEHAVIOR 17 (2008), available at http://www.instituteforlegalreform.com/get_ilr_doc.php?id=1218.

51. See Kathleen F. Brickey, Rethinking Corporate Liability Under the Model Penal Code, 19 RUTGERS L.J. 593, 629-30 (1988) (stating that six states that have adopted the Model Penal Code recognize that corporate liability may be limited by "due diligence" of managerial officials); see also H. Lowell Brown, Vicarious Criminal Liability of Corporations for the Acts of Their Employees and Agents, 41 LOY. L. REV. 279, 280 (1995) (suggesting that "a corporation which can establish the diligence of its compliance efforts should be absolved of vicarious liability for the acts of employees that contravene corporate policy and management directive"); Pamela $\mathrm{H}$. Bucy, Corporate Ethos: A Standard for Imposing Criminal Liability, 75 MINN. L. REV. 1095, 1099 (1991) (proposing a standard of liability under which "government can convict a corporation ... only if it proves that the corporate ethos encouraged agents of the corporation to commit the criminal act"); Developments in the Law, supra note 49, at 1241-58 (allowing a rebuttable presumption to vicarious liability with a due diligence defense); Gruner \& Brown, supra note 46, at 749-65 (recommending a due diligence defense to criminal corporate liability); Ellen S. Podgor, A New Corporate World Mandates a "Good Faith" Affirmative Defense, 44 AM. CRIM. L. REV. 1537, 1537-41 (2007); Charles J. Walsh \& Alissa Pyrich, Corporate Compliance Programs as a Defense to Criminal Liability: Can a Corporation Save Its Soul?, 47 RUTGERS L. REV. 605, 689 (1995) (arguing for a "corporate consciousness" defense so that a corporation can establish by a preponderance of the evidence that an employee's conduct is inconsistent with the corporation's "rational choice to do right or wrong" as demonstrated by its compliance program). With the new regulatory landscape, there is a renewed sense of urgency for serious consideration of a defense. But see generally Jennifer Arlen \& Reinier Kraakman, Controlling Corporate Misconduct: An Analysis of Corporate Liability Regimes, 72 N.Y.U. L. REV. 687 (1997) (exploring mixed-liability regimes, advocating for multiple tiers of liability based upon compliance, self-reporting, and cooperation, and asserting that a complete defense impedes the government's efforts to deter crime).

52. See Walsh \& Pyrich, supra note 51, at 689 (noting that the "offending employee's position" is crucial to the success of the due diligence defense). 
delay or decline indictment in exchange for the payment of significant fines, structural and personnel changes, and governance reforms. ${ }^{53}$

This Article argues that the government should be required to prove that the corporation or key decision makers had the requisite mens rea to commit the crime for which they are charged and proposes an affirmative defense to corporate criminal liability with a presumption against criminal charges and penalties. ${ }^{54}$ This framework would provide more leverage to the company during the investigation and negotiation stages. ${ }^{55}$ The new standard would also eliminate the disincentives of self-reporting criminal behavior that exist under current law. ${ }^{56}$ The new framework would motivate companies to actively police themselves and their employees, act quickly to terminate rogue

53. The difference between a DPA and an NPA is that, under a DPA, the Department of Justice (DOJ) files both the criminal information against the firm and the negotiated agreement in federal court. Under an NPA, prosecutors do not file formal charges and the private agreements are maintained by the parties. Memorandum from Craig S. Morford, Acting Deputy Att'y Gen. for Heads of Dep't Components and U.S. Atty's 1 (Mar. 7, 2008), available at http://www.justice.gov/dag/morford-useofmonitorsmemo-03072008.pdf. DPAs and NPAs serve the same function in that the company escapes criminal conviction so long as it complies with the terms of the agreement. See Lucinda A. Low et al., Settling an FCPA Enforcement Action: Contrasting NPAs, DPAs and Plea Agreements, ACI NATIONAL FCPA CONFERENCE 1, 8-9 (Nov. 9, 2011); see also A Resource Guide to the U.S. Foreign Corrupt Practices Act at 74-75, SEC. AND EXCH. COMM'N (Nov. 14, 2012), http://www.sec.gov/spotlight/fcpa/fcpa-resource -guide.pdf [hereinafter FCPA Guide] ("DPAs generally require a defendant to agree to pay a monetary penalty, waive the statute of limitations, cooperate with the government, admit the relevant facts, and enter into certain compliance and remediation commitments, including potentially a corporate compliance monitor . . . . A company's successful completion of a DPA is not treated as a criminal conviction."). The Guide differentiates an NPA from a DPA as not being filed with the court, but notes that an NPA is made public on the DOJ website if it is related to the Foreign Corrupt Practices Act, but is otherwise similar to a DPA in other respects.

54. See, e.g., Richard A. Epstein, Deferred Prosecution Agreements on Trial: Lessons from the Law of Unconstitutional Conditions, in PROSECUTORS IN THE BOARDROOM: UsING CRiminal Law to Regulate CoRPORATE CONDUCT 38, 45 (Anthony S. Barkow \& Rachel E. Barkow eds., 2011) ("In an ideal world, corporate criminal responsibility would give way to the exclusive use of civil sanctions."); Daniel R. Fischel \& Alan O. Sykes, Corporate Crime, 25 J. LEGAL STUD. 319, 324-32 (1996) (positing that, because civil remedies suffice, there is no benefit from attaching a moral stigma to a corporate entity; firms should not have to invest infinite resources to prevent employees from committing crimes); V.S. Khanna, Corporate Criminal Liability: What Purpose Does it Serve?, 109 HARV. L. REV. 1477, 1479 (1996) (stating that "a modified form of corporate civil liability could make corporate criminal liability obsolete by capturing the advantages of corporate criminal liability while avoiding or mitigating its disadvantages"); Andrew Weissmann with David Newman, Rethinking Criminal Corporate Liability, 82 IND. L.J. 411,412 (2007) (arguing that "[s]trict liability [for corporations] is antithetical to the dual goals in the criminal law of deterrence and retribution").

55. See Weissmann with Newman, supra note 54 , at 415 (noting that "[b]ecause the legal standard for liability informs settlement discussions, where a corporation can effectively show the government that it had an effective compliance system in place at the time of the misdeed, the responsible or wary prosecutor will relent.").

56. See WEISSMANN ET AL., supra note 50, at 17. 
employees, and cooperate with the authorities after unearthing wrongdoing. ${ }^{57}$ Most importantly, it would allow companies to make rational decisions about how much to invest in compliance programs. ${ }^{58}$

Part I of this Article discusses the history and current state of corporate criminal liability. Part II describes the Department of Justice's increasing use of DPAs and NPAs, which not only punish the conduct of an individual firm, but also regulate an entire industry in some cases. Part II also provides an overview of the current Guidelines, arguing that they have proved ineffective. Part III discusses the Foreign Corrupt Practices Act (FCPA) as a potential pilot for the defense. ${ }^{59}$ Additionally, Part III argues for an affirmative defense similar to the United Kingdom's Bribery Act $^{60}$ and the U.S. court system's current harassment and discrimination jurisprudence. Although the DOJ and Securities and Exchange Commission (SEC) issued comprehensive guidance on enforcement priorities for the FCPA in 2012, the Guide, albeit helpful, breaks no new ground, is not binding, does not and cannot constitute new law, and more important for the purposes of this Article, does not provide for any new defenses, least of all an affirmative defense for an effective compliance program. Part IV concludes that an affirmative defense will promote earlier detection and disclosure of the wrongdoing, reduce government expenditures,

57. See Bruce Reinhart, How Investing in Compliance Programs Can Mitigate Risk, SMART BuS. (July 1, 2012), http://www.sbnonline.com/2012/07/how-investing-in-compliance-programs -can-mitigate-risk/.

58. Id.

59. Foreign Corrupt Practices Act of 1977, Pub. L. No. 95-213, 91 Stat. 1494 (codified as amended at 15 U.S.C. $\$ \S 78 \mathrm{~m}(\mathrm{~b})$, (d)(1), (g)-(h), 78dd(1)-(3), 78ff (2006)).

In November 2012, the Criminal Division of DOJ and the Enforcement Division of the SEC released a joint document entitled $A$ Resource Guide to the U.S. Foreign Corrupt Practices Act. See generally FCPA Guide, supra note 53. The Guide was prompted in part by pressure for clarification on enforcement priorities from both the business community and from the U.S. govemment's international partners in the Organization for Economic Cooperation and Development (OECD). Id. at 8. Nonetheless, while the 120-page resource guide contains numerous hypotheticals and definitions, the Guide's opening disclaimer states clearly on its second page that it is "non-binding, informal and summary in nature ... does not constitute rules or regulations .... and does not in any way limit the enforcement intentions or litigating positions of [any] ... U.S. government agency." Id. at 2. Indeed, while detailed and helpful in some aspects, the Guide merely compiles information from statutes, opinion releases, enforcement actions, jury instructions, and other publicly available material.

Notably, though, the Guide does not add any new defenses for the FCPA, and for the reasons that follow, this Article argues that the government missed an opportunity for real reform for corporate compliance programs. While the Guide may lead clearly noncompliant companies to implement changes, most companies that already have some measure of a compliance program will likely have no incentive to do much more.

60. Bribery Act, 2010, c. 23, § 7(2) (U.K.); see also Koehler, supra note 28, at 609-10, 617-31 (arguing that the current FCPA enforcement regime does not provide a "sufficient return on ... compliance investments," examining the historical rationale for an affirmative defense, and proposing a defense in which a firm's pre-existing compliance policies and procedures and good faith efforts are incorporated into the FCPA as an element of the bribery offense). 
provide more comfort to investors and regulators, and allow the government to focus on punishing companies that have ineffective compliance programs.

\section{A BRIEF HISTORY OF CORPORATE CRIMINAL LIABILITY}

Although the basic tenet of criminal law is mens rea, ${ }^{61}$ corporations are held strictly liable for the acts of their employees if the employee acted within the scope of his or her employment and was motivated in some part to benefit the corporation. $^{62}$ In other words, the mens rea of the individual employee is more determinative than the instructions or prohibitions of the corporation's executive management or the board of directors. ${ }^{63}$

At common law, courts considered corporations artificial persons, separate in identity from their shareholders. ${ }^{64}$ In England, theories of corporate criminality began to grow out of public nuisance cases for deterrence by the 1600 s. $^{65}$ Most individuals, if they could even be identified, were unable to pay for the damage they caused as agents of the corporations. ${ }^{66}$ As one English judge noted, "A corporation is not indictable, but the particular members of it are." ${ }^{, 67}$ Nevertheless, judges applied standard criminal law principles to these artificial entities. ${ }^{68}$ In deciding how to convict a corporation, the peculiar form of a corporation troubled a nineteenth century English chancellor, who famously declared, "Did you ever expect a corporation to have a conscience, when it has no soul to be damned and no body to be kicked?"69 By the mid-nineteenth century, states began to pass laws regulating commercial activity regardless of the corporation's mens rea, because corporations, through their agents, continued to pollute the environment, endanger public health, and cause additional safety hazards. ${ }^{70}$ The legal fiction of the corporation and the

61. Frank J. Macchiarola, Finding the Truth in an American Criminal Trial: Some Observations, 5 CARDOZO J. INT'L \& COMP. L. 97, 107 (1997).

62. See Weissmann with Newman, supra note 54 , at 412 .

63. Id.

64. Id. at 418 .

65. V.S. Khanna, Corporate Crime Legislation: A Political Economy Analysis 7 (Univ. of Mich. John M. Olin Ctr. for Law \& Econ., Working Paper No. 03-012, 2003), available at http://papers.ssrn.com/sol3/papers.cfm?abstract_id=392121\#\#.

66. See id. at 7-8; Khanna, supra note 54, at 1495-96.

67. Anonymous Case (No. 935), (1701) 88 Eng. Re. 1518 (K.B.) 1518.

68. See Weissmann with Newman, supra note 54, at 418.

69. John C. Coffee, Jr., "No Soul To Damn: No Body To Kick": An Unscandalized Inquiry into the Problem of Corporate Punishment, 79 MICH. L. REV. 386, 386 (1981) (quoting Edward, First Baron of Thurlow, Lord Chancellor of England).

70. See Walsh \& Pyrich, supra note 51, at 614-15; see also Kathleen F. Brickey, Perspectives on Corporate Criminal Liability (Washington Univ. in St. Louis Sch. of Law Legal Studies Research Paper No. 12-01-02, 2012), available at http://papers.ssm.com/sol3/papers.cfm?abstract_id=1980346 (examining the DOJ's policies regarding the prosecution and punishment of corporations and how those policies are implemented in practice). 
status of its personality and culpability were the subject of debate until the early twentieth century. ${ }^{71}$

In 1909, the U.S. Supreme Court established the respondeat superior standard for the first time in the seminal case New York Central \& Hudson River Railroad Co. v. United States. ${ }^{72}$ The Court wrote:

Since a corporation acts by its officers and agents, their purposes, motives and intent are just as much those of the corporation, as are the things done. If, for example, the invisible, intangible essence or air which we term a corporation can level mountains, fill up valleys, lay down iron tracks, and run railroad cars on them, it can intend to do it, and can act therein as well viciously as virtuously . . . [a]pplying the principle governing civil liability, we go only a step farther in holding that the act of the agent, while exercising the authority delegated to him to make rates for transportation may be controlled in the interest of public policy, by imputing his act to his employer and imposing penalties upon the corporation for which he is acting in the premises.

Even though courts found the issue of corporate responsibility for the acts of employees a difficult one, subsequent courts held companies liable for their employees' actions even if the employee violated clear policies and directives. $^{74}$ In Continental Baking Co. v. United States, the Sixth Circuit Court of Appeals imposed liability on the corporation, holding "a corporation which employs an agent in a responsible position cannot say that the man was only 'authorized' to act legally and the corporation will not answer for his violations of law which inure to the corporation's benefit."75

The trend continued in United States v. Basic Construction Co., in which the jury convicted a company based on the actions of low-level employees despite

71. See Khanna, supra note 54, at 1479 (noting that "a more pragmatic approach [to criminal liability] was not developed until the twentieth century").

72. 212 U.S. 481,495 (1909) (finding liability where the railroad's freight traffic manager and assistant manager agreed to a freight rate below the railroad's published rate, thereby violating the Sherman Act).

73. Id. at 492-94 (quoting JOEL P. BISHOP, NEW COMMENTARIES ON THE CRIMINAL LAW: UPON A NEW SYSTEM OF LEGAL EXPOSITION VOL. I, at 255-56 (8th ed. 1892) (internal quotations omitted)).

74. See, e.g., In re Hellenic Inc., 252 F.3d 391, 395 (5th Cir. 2001) (finding that "[a]n agent's knowledge is imputed to the corporation where the agent is acting within the scope of his authority and where the knowledge relates to matters within the scope of that authority"); United States v. Sun-Diamond Growers of Cal., 138 F.3d 961, 970 (D.C. Cir. 1998) (holding that a corporation should be held liable for the actions of a vice president who schemed to defraud the company and finding that the facts did not preclude the conclusion that the vice president acted to benefit the corporation), aff'd on other grounds, 526 U.S. 398 (1999); United States v. Cincotta, 689 F.2d 239, $241-43$ (1st Cir. 1982) (finding that a corporation need not necessarily profit from the agents' actions to be held liable); see also Brown, supra note 51, at 286-88 nn.22-26 (containing a comprehensive list of similar cases).

75. 218 F.2d 137, 150 (6th Cir. 1960). 
evidence of the company's "longstanding, well known, and strictly enforced policy against bid rigging." 76 Similarly, in United States v. Hilton Hotels Corp., the Ninth Circuit Court of Appeals found the corporation liable under the Sherman Act for the actions of an uncooperative hotel purchasing agent who violated management's explicit and repeated instructions, determining that such liability would be an effective deterrent to corporate crime. ${ }^{77}$

As recently as 2009 , in a case in which a shipper was convicted for its crew's failure to follow the Act to Protect Pollution from Ships, the Second Circuit dismissed the argument that the government must prove that the defendant lacked appropriate policies and procedures to prevent legal violations. $^{78}$ Instead, the court held that compliance programs do not safeguard a corporation from legal responsibility regardless of whether the employee was knowingly violating the law. ${ }^{79}$

\section{A. The Effects of Respondeat Superior Liability on Corporate Criminality}

Both logic and law dictate that a corporation acts through its employees as agents. ${ }^{80}$ The respondeat superior principles that courts use to impute liability stem from tort law's agency principles, which hold companies responsible for the acts of their employees. ${ }^{81}$ The only relevant factor that criminally and civilly binds the company to the illegal act is the agent's apparent authority and his or her own mens rea, which courts substitute for the corporation's, even if

76. 711 F.2d 570, 572 (4th Cir. 1983). The jury instruction read, "a corporation may be held criminally responsible for antitrust violations committed by its employees if they were acting within the scope of their authority or apparent authority and for the benefit of the corporation, even if . . . such acts were against the corporate policy or express instructions." Id. at 573 .

77. 467 F.2d 1000, 1004-07 (9th Cir. 1972). The Court ruled against Hilton notwithstanding that the rogue employee admitted that he disobeyed management's instructions out of "anger and personal pique toward the individual representing the supplier." Id. at 1004.

78. United States v. Ionia Mgmt. S.A., 555 F.3d 303, 310 (2d Cir. 2009).

79. Id. (citing United States v. Twentieth Century Fox Film Corp., 882 F.2d 656, 660 (2d Cir. 1989)).

80. Brickey, supra note 70 , at 11 .

81. See Developments in the Law, supra note 49, at 1247. The Restatement (Third) of Agency states

(1) An employer is subject to vicarious liability for a tort committed by its employee acting within the scope of employment.

(2) An employee acts within the scope of employment when performing work assigned by the employer or engaging in a course of conduct subject to the employer's control. An employee's act is not within the scope of employment when it occurs within an independent course of conduct not intended by the employee to serve any purpose of the employer.

(3) For purposes of this section,

(a) an employee is an agent whose principal controls or has the right to control the manner and means of the agent's performance of work, and

(b) the fact that work is performed gratuitously does not relieve a principal of liability.

RESTATEMENT (THIRD) OF AGENCY $\$ 7.07$ (2006). 
the conduct was expressly prohibited. ${ }^{82}$ Thus, lawmakers and judges must determine whether those employees are "purely self-interested" or if other factors are relevant. $^{83}$

If a corporation's agents act in the company's rational economic interest, a strict vicarious liability standard appears reasonable. ${ }^{84}$ First, the standard should serve as a deterrent. ${ }^{85}$ Classical theory divides deterrence into two categories-general and specific. ${ }^{86}$ General deterrence dissuades other potential perpetrators, after seeing a company and its employee punished, from committing the same or a similar crime. ${ }^{87}$ Specific deterrence focuses on the actual wrongdoer and aims to prevent the culpable firm from committing future crimes by imposing sanctions or requirements that force the corporate officers to enact policies, procedures, monitoring, and auditing measures. ${ }^{88}$

If a corporation acts in its own self-interest, it will rationally weigh the economic benefits of committing a crime with the costs, including paying substantial fines or risking debarment from government contracts or other lucrative business dealings. ${ }^{89}$ If perceived costs are lower than the perceived benefits, the firm will likely take more risks. ${ }^{90}$ But, if the costs equal or exceed the harm to society and the benefit to the firm, the firm will likely take fewer risks. 91

Second, the company is in a better position than the government to control its employees because it has visibility of agents' day-to-day activities, understands the industry, can more easily identify the wrongdoer, and can set

82. See Weissmann with Newman, supra note 54 , at 422 n.35; see also Brickey, supra note 70 , at 11 (noting that "even though the agent's conduct may actually harm the corporation, the wrongful acts are attributable to the company as long as the agent was acting within the scope of authority (broadly construed) and with intent to benefit the corporation").

83. See, e.g., Lynn Stout, Killing Conscience: The Unintended Behavioral Consequences of 'Pay For Performance' 2 (Jan. 2011) (unpublished manuscript) (on file with author).

84. See Arlen \& Kraakman, supra note 51, at 693 (stating that "firms often will be better than government officials at monitoring or investigating agent misconduct"); see also Brown, supra note 51, at 284 (arguing that "the purpose to be served by imposing liability on corporations is to deter criminal conduct in the name of the corporation by denying the owners the benefits of the prohibited conduct, thereby providing a direct incentive to the owners to assure compliance with the law").

85. See Brown, supra note 51, at 284 (noting that the purpose of corporate liability is to deter criminal behavior).

86. See Brickey, supra note 70, at 14-16 (describing the two types).

87. See id. at 14-15.

88. See id. at 16.

89. See Walsh \& Pyrich, supra note 51, at 632-33.

90. See id. at $633 \mathrm{n} .93$ (stating that a corporation will act to achieve economic benefits unless there are substantial penalties).

91. See Coffee, supra note 69 , at 389 (noting that, generally, an actor contemplating committing a crime will only be deterred if costs outweigh benefits). 
incentives or punishments for inappropriate behavior. ${ }^{92}$ If the firm can only punish the harm by termination, the government may imprison the employee or garnish wages from the employee's future employer. ${ }^{93}$

Additionally, the firm has a common law duty to supervise its employees; therefore, a vicarious liability standard provides the incentive to supervise properly. ${ }^{94}$ Instead of setting goals that pressure employees to break the law in order to meet unattainable targets, corporations would focus on achievable goals without an incentive to engage in a criminal act. ${ }^{95}$

Another argument is that the company may not reap the benefit of an employee's bad act yet also absolve itself of responsibility by stating that a company policy was in place to prohibit the behavior. ${ }^{96}$ Whether or not the agent ignored instructions, the illegal behavior will likely provide the company with short-term economic benefits until the wrongdoing is revealed. Otherwise, the agent would not risk the action, unless the agent was acting only in his or her own interests. ${ }^{97}$

A corporate entity also has the ability to inflict greater harm on society compared to an individual criminal; thus, it must be given a higher standard of criminal liability. ${ }^{98}$ Punishing the firm for the employee's actions satisfies society's need for retribution."

Further, criminal law aims to rehabilitate, which is especially relevant in the corporate context when the employees who committed the wrongdoing will likely be terminated. ${ }^{100}$ The sanctions imposed after companies are charged and agree to either DPAs or NPAs can also change the company culture. ${ }^{101}$

92. See Wallace P. Mullin \& Christopher M. Snyder, Corporate Crime 13 (Dec. 13, 2007) (unpublished manuscript prepared as chapter to forthcoming 11 ENCYCLOPEDIA OF LAW AND ECONOMICS (Nuna Garoupa ed.)) available at http://www.dartmouth.edu/ csnyder /crimesurvey19.pdf. (providing examples of how a company is better suited to control its agents).

93. See id. at 13-14 (describing the limitations to punishing inappropriate conduct that a company may face).

94. See Brown, supra note 51, at 295.

95. See id. at 313-14 n.125.

96. See N.Y. Cent. \& Hudson River R.R. Co. v. United States, 212 U.S. 481, 493 (1909) (holding that, in cases in which an employee acts "against the express orders" of a corporation, the corporation may be held liable for damages not "because the [corporation] actually participates in the malice or fraud, but because the act is done for the benefit of the [corporation] . . . and justice requires that the latter shall be held responsible for damages").

97. See Walsh \& Pyrich, supra note 51, at 623-24.

98. See Brickey, supra note 70 , at 3-6 (providing examples of corporate activities that cause societal harm).

99. See Peter J. Henning, Corporate Criminal Liability and the Potential for Rehabilitation, 46 AM. CRIM. L. REV. 1417, 1420 (2009) (discussing the importance of having corporate criminal liability as an "expressive function" of retribution in society).

100. See id. at 1427-28 (discussing rehabilitation in the context of corporate criminal law).

101. Id. (arguing that DPAs and NPAs are a "worthwhile means to resolve investigations" and that "the use of the criminal law should be directed primarily toward enabling the corporation to reform itself'). 
However, there are more compelling arguments on the other side. Vicarious corporate liability requires the cost of wrongdoing to be passed onto innocent parties who have not committed the illegal acts and do not have the ability to stop them. ${ }^{102}$ After a large financial penalty, bondholders, creditors, stockholders, and consumers all experience losses. ${ }^{103}$

Further, the vicarious liability standard does not necessarily deter corporate crime. ${ }^{104}$ Many corporate crimes such as dumping hazardous waste or antitrust violations are not easy to detect while there is still ongoing harm. ${ }^{105}$ The victims may be unaware of the harms at the time they occur and/or perpetrators may have left the corporation or are difficult to identify once the government discovers the crime. ${ }^{106}$ Although the difficulty of detecting harms may seem like an argument in favor of vicarious liability, it only addresses punishment, not deterrence. ${ }^{107}$ Vicarious liability should prompt the company to discover and stop illegal conduct, but it may actually cause the company to ensure that illegal acts are more difficult to identify. ${ }^{108}$ For example, environmental crimes may be particularly easy to hide because they are difficult to detect and the harms may remain hidden for years before its effects harm the public. ${ }^{109}$

Moreover, a company cannot exercise complete control over its employees. ${ }^{110}$ The employee's and company's interests may diverge if the rogue employee is more fearful of his own termination or loss of a bonus than the company's prosecution for the illegal act committed to meet those

102. See Walsh \& Pyrich, supra note 51, at 643-44.

103. See Coffee, supra note 69 , at 401,413 (proposing that high fines should be levied in equity securities and placed in a fund to compensate victims so that only stockholders, who indirectly benefitted from the crime, bear the penalty); see also Walsh \& Pyrich, supra note 51, at 643.

104. See Geraldine Szott Moohr, On the Prospects of Deterring Corporate Crime, 2 J. BUS. \& TECH. L. REV. 25, 26-27 (2007) (discussing how respondeat superior, which became the "federal standard for corporate criminal liability," has been viewed with increasing skepticism for its failure to deter corporate crimes in several highly publicized cases of corporate fraud).

105. See Coffee, supra note 69, at 391 (addressing the difficulty in exposing certain crimes).

106. Id. at 390-91 (explaining how "victims of many corporate crimes do not necessarily know of their injury"); see also supra note 66 and accompanying text.

107. See Timothy Coleman, Panel Discussion, Bigger Carrots and Bigger Sticks: Issues \& Developments in Corporate Sentencing, 11 FORDHAM J. CORP. \& FIN. L. 162, 167 (2006) (noting that punishing an employee may not deter the entire company from engaging in inappropriate acts).

108. Jennifer Arlen, The Potentially Perverse Effects on Corporate Criminal Liability, $23 \mathrm{~J}$. LEGAL STUDIES 833, 843 (1994).

109. See Michael M. O'Hear, Sentencing the Green-Collar Offender: Punishment, Culpability, and Environmental Crime, 95 J. CRIM. L. \& CRIMINOLOGY 133, 261 (2004) (explaining that environmental crimes are difficult to detect and may not produce harm for many years).

110. See Coffee, supra note 69 , at 394 . Behavioral economists have found that firms that value aggressive managers may attract over-confident risk-takers who may not appropriately appreciate the risks to the corporation. See Moohr, supra note 104, at 30. 
objectives. ${ }^{111}$ In other words, the agent may be more willing to engage in illegal behavior if he does not believe that the corporation or the government will uncover his wrongdoing, but believes that the corporation can easily learn that he has not met his objectives. ${ }^{112}$ Unlike the employee who embezzles from the company to exclusively serve his or her own economic interest, the rogue employee who, for example, manipulates numbers to increase profitability and raise share prices, ostensibly acts for the company's benefit and his or her own interests as well. ${ }^{113}$ The conflict between engaging in illegal behavior for the benefit of the company and the risk of job loss may tempt an employee to ultimately take the risk of committing an illegal act. ${ }^{114}$ Notwithstanding policies prohibiting inappropriate conduct, this risk-taking implicates the company regardless of the company's intent. ${ }^{15}$

Vicarious liability may not adequately serve punishment goals. ${ }^{116}$ Because companies cannot risk trial and a possible subsequent conviction, they negotiate their penalties with prosecutors through DPAs and NPAs, thereby escaping the potentially larger fines that could be levied by a court or imposed by a jury ${ }^{117}$ To some companies, fines may be just another cost of doing business. ${ }^{118}$ Even with the ability to negotiate the terms of the penalties, the corporation does not have sufficient incentives to properly train and monitor its employees or to disclose the wrongful conduct to the government because it faces criminal liability and fines regardless of its actions. ${ }^{119}$ Compounding the

111. See Coffee, supra note 69, at 393-94.

112. Id. at 399; see also Mullin \& Snyder, supra note 92, at 34 (showing that incentive pay and stock options may increase a manager's incentive to misreport earnings).

113. See Coffee, supra note 69, at 397-99.

114. See id. at 399 (explaining that the manager is "[c]aught between Scylla and Charybdis" because he faces counter-balancing disincentives to either act illegally for the benefit of the corporation or lose his job).

115. See supra note 62 and accompanying text.

116. See Jennifer Arlen, Corporate Criminal Liability: Theory and Evidence 145 (N.Y. Univ. Sch. of Law, N.Y.U. Ctr. for Law, Econ. \& Org., Law \& Econ. Research Paper Series, Working Paper No. 11-25, 2012), available at http://papers.ssm.com/sol3/papers.cfm?abstract_id $=1890733$.

117. See infra Part II.

118. See Coffee, supra note 69, at 389. Ironically, research shows that a company's cooperation with the SEC increases the likelihood of sanctions due to the amount of information the agency receives but decreases the amount of the monetary penalties. Rebecca Files, $S E C$ Enforcement: Does Forthright Disclosure and Cooperation Really Matter? at 5, 35 (Univ. of Tex. at Dallas Sch. of Mgmt. Draft, 2011), available at http://papers.ssm.com/sol3/papers.cfm?abstract_id=1640064. The firm is better off not monitoring its employees actions so that its does not have to face the disclosure dilemma. See Arlen, supra note 108, at 836 (noting that if the expected cost to the corporation of the resulting increase in its expected criminal liability exceeds the expected benefit of the reduction in the number of crimes, a corporation will not respond by increasing its enforcement expenditures because additional enforcement will only increase the firm's expected liability); see also Arlen, supra note 116, at 145 (arguing that respondeat superior deters corporate policing).

119. See supra notes $27-28$ and accompanying text. 
matter, disclosure to the government, investors, and the public exposes the company to lawsuits from aggrieved shareholders and risks harm to the company's reputation, which can adversely affect future business opportunities and share prices. ${ }^{120}$

If corporations do not have enough incentive to prevent and detect crimes within their own organizations, then the rational decision is to under-invest in training employees and developing compliance programs. ${ }^{121}$ Thus, vicarious liability fails from both deterrence and punishment perspectives. ${ }^{122}$ Although the rehabilitation theory has some merit, it is not strong enough to countervail the shortcomings of the deterrent and punishment theories. ${ }^{123}$ Further, the prevailing respondeat superior theory is reactive rather than proactive and inevitably involves pitting the company against the accused employee for defense purposes. ${ }^{124}$

\section{B. Alternative Theories of Liability}

\section{The Model Penal Code}

The Model Penal Code (MPC) only imposes liability on a company if the board of directors or upper level management knew or should have known of the conduct. ${ }^{125}$ This theory permits an affirmative defense when officers exercised appropriate due diligence to prevent the crime. ${ }^{126}$ The firm should prevail unless "the offense consists of an omission to discharge a specific duty of affirmative performance imposed on associations by law ... [or if it] is plainly inconsistent with the legislative purpose in defining the particular

120. See Arlen, supra note 116, at 149.

121. See Arlen, supra note 108 , at 836 (noting that "[i]f the expected cost to the corporation of the resulting increase in its expected criminal liability exceeds the expected benefit to the corporation of the reduction in the number of crimes, a corporation subject to strict vicarious liability will not respond by increasing its enforcement expenditures because additional enforcement would only increase the firm's expected criminal liability"); see also Mullin \& Snyder, supra note 92 , at 15 (stating that "[a]/ternatively, the state can induce the principal to adopt appropriate monitoring systems through direct fiat or by having a negligence standard for monitoring systems").

122. See supra notes $117-20$ and accompanying text.

123. See Henning, supra note 99 , at 1420 (noting the weaknesses of deterrence and retribution theories and explaining the benefits of rehabilitation theory-the notion that the government can enter into agreements with errant corporations to correct their behavior-thus preventing further crimes).

124. See Mullin \& Snyder, supra note 92, at 16-17 (observing that inducing the principal and the agent to report on each other in a version of the "Prisoner's Dilemma," allows the state to reward reporting without significantly reducing the sanctions, yet does not discourage the principal from self-reporting if the information is used against the enterprise).

125. MODEL PENAL CODE $\$ 2.07(1)$ \& explanatory note (1985). Over thirty-six states have adopted the MPC in full or in part and several others have been influenced by it. Francis $X$. Shen et al., Sorting Guilty Minds, 86 N.Y.U. L. REV. 1306, 1318 (2011).

126. MODEL PENAL CODE § 2.07(5). 
offense."127 However, the MPC is also flawed because it may allow executives with a head-in-the-sand mentality to claim that their employees acted without authority. ${ }^{128}$ This standard may have unintended consequences by discouraging higher-level employees from properly supervising lower-level employees. ${ }^{29}$ Furthermore, without a more detailed description of what constitutes an affirmative due diligence defense, this theory, although fairer than the vicarious liability standard, still will not provide the certainty that firms need to spur comprehensive deterrence and detection programs. ${ }^{130}$

\section{The Collective Action Doctrine}

Under the collective action doctrine, courts have convicted corporations of intent-based crimes even if individual agents possessed the requisite mens rea. ${ }^{131}$ In United States $v$. Bank of New England, a court instructed the jury that it did not need to find that any one individual had knowledge of the legal requirements or intent to violate those requirements in order to convict the corporation. ${ }^{132}$ But, if the fact-finder cannot determine who had the requisite intent, then how can the court or jury decide whether the wrongdoer acted to benefit the corporation rather than his or her own interests? Because a rational company will know that it will be held responsible, this standard does even less to deter corporate wrongdoing or inspire extra efforts to ensure that employees act lawfully. ${ }^{133}$ Even with the courts' failure to take a company's prevention efforts into consideration, companies have still endeavored to establish compliance programs. ${ }^{134}$ Unfortunately, not only have these programs failed to save companies from vicarious liability, but they have also been relatively unpersuasive to prosecutors. ${ }^{135}$

127. Id. § 2.07(3)(b), (5).

128. See Christopher R. Green, Punishing Corporations: The Food-Chain Schizophrenia in Punitive Damages and Criminal Law, 87 NEB. L. REV. 197, 212 (2008) (explaining that a restrictive rule like MPC $\S 2.07$ may be too restrictive because employees may develop and engage in practices without a managerial agent's knowledge or direction).

129. See Bucy, supra note 51, at 1100 .

130. See William S. Laufer, Corporate Liability, Risk Shifting, and the Paradox of Compliance, 52 VAND. L. REv. 1343, 1369-71 (1999).

131. See United States v. Bank of New England, 821 F.2d 844, 855 (1987).

132. Id. (finding that the culpability of a corporation, which was charged with criminal violations of the Currency Transaction Reporting Act, was based on the knowledge of one individual bank supervisor).

133. See id. at 856 (quoting United States v. T.I.M.E.-D.C., Inc., 381 F. Supp. 730, 738 (W.D. Va. 1974)).

134. See infra note 183 and accompanying text.

135. See United States v. Ionia Mgmt. S.A., 555 F.3d 303, 310 (2d Cir. 2009). 


\section{THE DEPARTMENT OF JUSTICE'S ROLE IN IMPOSING CORPORATE CRIMINAL LIABILITY}

\section{A. DOJ Guidelines and Deferred Prosecution Agreements}

The DOJ developed DPAs as a strategy to better detect and sanction wrongdoers by encouraging corporations to self-report and cooperate with federal authorities. ${ }^{136}$ DPAs are akin to probation because they allow a corporate defendant to escape indictment and the entering of a guilty plea, provided the company completes negotiated mandates and does not commit another crime during the term of the agreement. ${ }^{137}$ In exchange for dropping charges, prosecutors typically require that companies admit to certain facts, institute or reform corporate ethics and compliance programs, pay restitution to victims, cooperate with ongoing investigations of individuals, and, in some cases, hire a monitor for a specified period of time. ${ }^{138}$ Under the government's

136. See Jennifer Arlen, Removing Prosecutors from the Boardroom: Limiting Prosecutorial Discretion to Impose Structural Reforms, in PROSECUTORS IN THE BOARDROOM: USING CRIMINAL LAW TO REgUlate CORPORATE CONDUCT 62, 62 (Anthony S. Barkow \& Rachel E. Barkow eds., 2011). The failure of the accounting firm Arthur Andersen is the most cited example of the kind of "death penalty" that can result from a corporate criminal prosecution. See Ellen S. Podgor, White Collar Innocence: Irrelevant in the High Stakes Risk Game, 85 CHI.-KENT L. REV. 77, 80-81, 87 (2010) (discussing the demise of Andersen). Andersen purportedly refused to enter into a DPA because of the possibility that the SEC would bar the firm from auditing public companies after the firm pleaded guilty to a felony. Brickey, supra note 70, at 17.

137. See Weissmann with Newman, supra note 54, at 413.

138. See Coleman, supra note 107 , at 176 ; see also Epstein, supra note 54, at 57 ("Congress ... should ... șcrap the doctrine of corporate criminality altogether. So long as corporate criminality is available, prosecutors can use the threat of indictment as a club to beat down legitimate corporations."). Of the fifty-seven agreements that the Government Accountability Office reviewed in 2008 and 2009, twenty-six required the company to hire and pay for a monitor. See Corporate Crime: Preliminary Observations on DOJ's Use and Oversight of Deferred Prosecution and Non-Prosecution Agreements: Hearing Before the Subcomm. on Commercial and Admin. Law of the H. Comm. on the Judiciary, 111th Cong. 2-3 (2009) [hereinafter Corporate Crime] (statement of Eileen R. Larence, Director, Homeland Security, U.S. Government Accountability Office). In the past, prosecutors have also required companies to cease paying the legal fees for employees in order to prove good-faith cooperation, thereby pitting the company against its employees and deleteriously affecting the employees' constitutional rights. See Memorandum from Mark Filip, Deputy Att'y Gen., U.S. Dep't of Justice to Heads of Dep't Components and U.S. Attorneys on Principles of Federal Prosecution of Business Organizations 8 (Aug. 28, 2008), available at $\mathrm{http} / / / \mathrm{www}$.justice.gov/dag/readingroom/dag-memo-08282008.pdf. The DOJ changed its position, stating that prosecutors should no longer ask corporations not to assist employees in their legal defense and has instituted a policy forbidding prosecutors from asking for attorney-client privileged information or attomey work product, with limited exceptions. See id. at 8-9, 13. This change in tone arose after a case involving a KPMG tax shelter, in which the U.S. District Court for the Southern District of New York identified constitutional issues with DOJ's insistence that KPMG not fund its employees' defense. United States v. Stein, 495 F. Supp. 2d 390, 414 (S.D.N.Y. 2007) (finding that the DOJ's "deliberate interference with the defendants' rights was outrageous and shocking in the constitutional sense because it was 
rationale, not only does the prosecution send a powerful message of deterrence to the company, but it also has the potential to change an industry. ${ }^{139}$

Generally, prosecutors refer to the Principles of Federal Prosecution of Business Organizations (Principles) when conducting an investigation, determining whether to bring charges, and negotiating plea agreements. ${ }^{140}$ The Principles provide numerous factors to consider, including: (1) the nature and seriousness of the offense; (2) involvement of upper management; (3) the corporation's history of similar offenses; (4) voluntary disclosure and cooperation; (5) any remedial actions taken; (6) harm to innocent stakeholders as a result of prosecution; (7) the existence and adequacy of a compliance program; (8) the adequacy of individual prosecution; and (9) the adequacy of civil remedies. $^{141}$

Additionally, prosecutors rely on information from the companies under investigation and feedback from regulatory agencies. ${ }^{142}$ Although only the DOJ can initiate criminal cases against firms, a number of referrals come from other agencies, such as the SEC, or through private parties via the False Claims Act of 1986 (FCPA). ${ }^{143}$

fundamentally at odds with two of our most basic constitutional values - the right to counsel and the right to fair criminal proceedings").

139. See Arlen, supra note 136, at 62 ("Prosecutors in the United States are no longer content to sanction corporations for their employees' crimes. They also now regularly intervene in corporations' internal affairs by pressuring firms to adopt structural reforms ostensibly designed to reduce the likelihood of future wrongdoing."); see also Coleman, supra note 107, at 167 ("Prosecuting the corporation criminally . . . gives an opportunity to send a very powerful message of deterrence ... that can resound throughout an industry ... to change their behavior, and can even have effects across the entire economy.").

140. See infra note 141 and accompanying text.

141. See Memorandum from Larry D. Thompson, Deputy Att'y Gen. to Heads of Dep't Components and U.S. Attorneys on Principles of Federal Prosecution of Business Organizations (Jan. 20, 2003) [hereinafter Thompson Memorandum], available at http://www.justice.gov/dag/cttf/corporate_guidelines.htm. Recently, the DOJ reaffirmed the corporate vicarious liability standard, noting that a corporation may be held criminally liable for the illegal acts of its directors, officers, employees, and agents acting within the scope of their duties and where the acts were intended, at least in part, to benefit the corporation. See Memorandum from Paul J. McNulty, Deputy Att'y Gen. to Heads of Dep't Components and U.S. Attomeys on Principles of Federal Prosecution of Business Organizations (Dec. 12, 2006), available at http://www.justice.gov/dag/speeches/2006/mcnulty_memo.pdf (replacing the Thompson Memorandum); see also FCPA Guide, supra note 53, at 52-53.

142. Corporate Crime, supra note 138 , at 4.

143. 31 U.S.C. § 3730(b) (2006). In 2002, the Corporate Fraud Enforcement Task Force was created to promote collaboration between federal agencies and prosecutors in investigating and prosecuting firms. See Exec. Order No. 13,271, 3 C.F.R. 245 (2002). After the 2008 financial crisis, President Obama established the Financial Fraud Task Force to replace the 2002 entity. See Press Release, Dep't of Justice Office of Pub. Affairs, President Obama Establishes Interagency Financial Fraud Enforcement Task Force (Nov. 17, 2009), available at http://www.justice.gov/opa/pr/2009/November/09-opa-1243.html. 
In recent years, the DOJ and the SEC have made more frequent use of DPAs and NPAs, ${ }^{144}$ despite inconsistent interpretation of each agreement's definition. $^{145}$ Significantly, nearly half of the twenty-nine DPAs in 2011 related to the FCPA, which makes crimes under the statute an appropriate pilot for an affirmative defense. ${ }^{146}$ Many attribute the rise of DPAs to the issuance of the 2003 Thompson Memorandum, in which then Deputy Attorney General Larry Thompson ${ }^{147}$ instructed: "Corporations should not be treated leniently

144. Prosecutors and companies entered into only eleven DPAs and NPAs between 1993 and 2001. Peter Spivack \& Sujit Raman, Regulating the 'New Regulators': Current Trends in Deferred Prosecution Agreements, 45 AM. CRIM. L. REV. 159, 159 (2008) (stating that DPAs and NPAs are "proliferating"). Then, the pace increased; parties entered into two agreements in 2002, six in 2003, eight in 2004, thirteen in 2005, twenty-four in 2006, thirty-nine in 2007, nineteen in 2008, twenty in 2009, forty in 2010, and twenty-nine in 2011. GIBSON DUNN, 2011 YEAR-END UPDATE ON CORPORATE DEFERRED PROSECUTION AND NON-PROSECUTION AGREEMENTS 2 (2012), available at http://gibsondunn.com/publications/Documents/2011YearEnd Update-CorporateDeferredProsecution-NonProsecutionAgreements.pdf.

145. Corporate Crime, supra note 138 , at 1 (noting various perceptions of what defines a DPA and an NPA and conflicting opinions on whether the DOJ Guidelines are mandatory); see also ANGela J. DAvis, ARBITRARY JUSTICE: THE POWER OF THE AMERICAN PROSECUTOR 16 (2007) (observing that there is no legal requirement to follow the U.S. Attorneys' Manual and that prosecutors are not "accountable to anyone outside the [DOJ] if . . . they fail to follow their own rules").

146. See GIBSON DUNN, supra note 144, at 4 (stating that the FCPA accounted for forty-one percent of the agreements).

147. Thompson is one of several former DOJ officials and members of the judiciary now calling for an affirmative defense. See Larry Thompson, The Blameless Corporation, 46 AM. CRIM. L. REV. 1323, 1326 (2009) (proposing the new compliance program affirmative defense, which requires the corporation to put the government on notice that it plans to assert the defense and the court to rule on it before trial); see also Foreign Corrupt Practices Act: Hearing Before the Subcomm. on Crime, Terrorism, and Homeland Security of the H. Comm. on the Judiciary, 112th Cong. 19-45 (2011) [hereinafter FCPA Hearing] (testimony of the Hon. Michael Mukasey, former Att'y Gen., Partner, Debevoise \& Plimpton, LLP; George Terwilliger, III, Partner, White \& Case LLP and former Deputy Att'y Gen.), available at http://judiciary.house.gov/hearings/printers/112th/112-47_66886; ANDREW WEISSMANN \& AliXANDRA SMITH, RESTORING BALANCE: PROPOSED AMENDMENTS TO THE FOREIGN CORRUPT PRACTICES ACT 6-7 (2010) (Weissmann is the former Director of the Enron Task Force, Chief of the Criminal Division in the U.S. Attorneys' Office for the Eastern District of New York, and FBI General Counsel as of January 2012); Dick Thornburgh, The Dangers of Over-Criminalization and the Need for Real Reform: The Dilemma of Artificial Entities and Artificial Crimes, 44 AM. CRIM. L. REV. 1279, 1279-80 (2007) (remarking that there are now "artificial crimes" that criminalize acts that do not cause any cognizable harm to either people or property); Mary Jo White, Corporate Criminal Liability: What Has Gone Wrong?, 37 ANN. INST. SEC. REG. 815, 818 (2005) (observing that the Thompson Memorandum factors are "being used by some prosecutors, not so much as factors in making their charging decisions, but as means to force companies to behave and reform themselves as the prosecutors, fashioning themselves as the new corporate governance experts"); Alberto R. Gonzales, former Attomey Gen., "In Pursuit of Justice", Prepared Remarks at the Lawyers for Civil Justice Meeting (May 2012), available at http://www.wallerlaw.com/portalresource/lookup/wosid/cp-base-4-13102 /media.name=/TAP\%20-\%20Speech\%20to\%20LCJ\%20by\%20Judge\%20Gonzales\%202012\%20 
because of their artificial nature nor should they be subject to harsher treatment. Vigorous enforcement of the criminal laws against corporate wrongdoers, where appropriate[,] results in great benefits for law enforcement and the public, particularly in the area of white collar crime." 148 In addition to the Thompson Memorandum, the demise of Enron and public clamor for harsher sentences for corporations contributed to the rise in DPA and NPA agreements after 2003 . $^{149}$

From the DOJ's perspective, these agreements serve the goals of punishing and deterring corporate criminal conduct, extracting restitution for innocent victims, and instilling a stronger compliance culture into an organization without the hammer of prosecution. ${ }^{150}$ In recent years, however, DPAs and NPAs have come under fire from those who point out the "[g]rossly disproportionate power" that prosecutors, with little external oversight or expertise in business, have over risk-averse corporations. ${ }^{151}$

In addition to potential reputational damage, many companies face public disclosures, possible default on collateral loans, suspension or debarment from federal contracts or subcontracts, and/or loss of licenses or customers upon indictment. ${ }^{152}$ Therefore, many do not want to take the chance defending themselves. $^{153}$ This damage may even occur at the indictment stage before a

05.pdf ("I do not support bribery, but I support reforms to the FCPA that add] a compliance defense and a willfulness requirement for corporate criminal liability.").

148. See Thompson Memorandum, supra note 141, at 2.

149. See Lawrence D. Finder \& Ryan D. McConnell, Devolution of Authority: The Department of Justice's Corporate Charging Policies, 51 ST. LOUIS U. L.J. 1, 1 (2006).

150. See, e.g., Corporate Crime, supra note 138, at 2.

151. Weissmann with Newman, supra note 54, at 414; see also Arlen, supra note 136, at 63 (noting that prosecutors have little if any external oversight when they require compliance programs and other structural reforms through DPAs and NPAs, whereas regulatory agencies have more oversight and expertise to assess appropriate remedial measures); William S. Laufer, Corporate Prosecution, Cooperation and the Trading of Favors, 87 IOWA L. REV. 643, 653 (2002) (observing that "[e]very year following passage of the Sentencing Guidelines, there has been a noticeable escalation in prosecutorial expectations of organizational cooperation"); John Hasnas, Rethinking Vicarious Criminal Liability: Corporate Culpability for White-Collar Crime, Web Memo (Heritage Foundation, D.C.), Aug. 15, 2006, at 2, available at http://www.heritage.org/research/reports/2006/08/rethinking-vicarious-criminal-liability-corporat e-culpability-for-white-collar-crime ("Under the present standard of corporate criminal responsibility, whenever one of its employees comes under suspicion of criminal wrongdoing, the corporation faces the stark choice of either betting the company's future that the employee will be exonerated or doing whatever DOJ demands to avoid corporate indictment.").

152. See Brown, supra note 51, at 321-22. The government itself acknowledges the harsh collateral damage that can result from guilty pleas, DPAs, and NPAs even if companies do not face automatic debarment from government contracting. For example, independent debarment authorities can consult with the DOJ regarding a company's conduct, and the company and prosecutors many not negotiate away another agency's right to debar a company from doing business with the government or for the company to be de-listed from government contracts as part of the plea bargaining process. See FCPA Guide, supra note 53, at 70 .

153. See Brown, supra note 51, at 321-22. 
conviction. ${ }^{154}$ Federal procurement regulations prevent companies under investigation or indictment from applying for or receiving federal contracts, assistance, or subsidies. ${ }^{155}$ Companies may also lose their licenses to export goods during the term of the DPA. ${ }^{156}$

This leverage leads to agreements that extend far beyond the individual firm's culpability, resulting in extraordinary remedies, such as a provision of millions of dollars in free medical care for a campaign contribution crime, the creation of 1600 jobs after a charge of fraud, and even the endowment of a university's ethics chair in the name of the U.S. Attorney prosecuting a company for securities law violations. ${ }^{157}$

Of course, corporations cannot be sent to jail; therefore, paying large fines is their punishment. ${ }^{158}$ In addition to the imposition of the traditional fines and penalties for the crime charged, the range of mandates in some DPAs and NPAs require personnel changes, governance reforms, revision of business models, and other intrusions into the internal operations of the firm such that prosecutors have begun to act as regulators ${ }^{159}$ and, in a sense, as the board of directors. ${ }^{160}$ In some extreme cases, prosecutors have mandated that entire industries change practices. ${ }^{161}$ Despite the potentially far-reaching effects of

154. See Epstein, supra note 54, at 40.

155. See 48 C.F.R. $\$ \S 9.405-.406$ (2011); see also Brown, supra note 51, at 321 (noting that limiting favorable treatment to the sentencing state is too late-criminal prosecution can result in suspension or debarment and stigma issues); Epstein, supra note 54, at 40. Similar prohibitions exist for those companies participating in federally subsidized health care programs. See 42 C.F.R. $\$ 1001.1901$ (2011).

156. Foreign Corrupt Practices Act Antibribery Provision, U.S. DEP'T OF JUST., http://www.justice.gov/criminal/fraud/fcpa/docs/lay-persons-guide.pdf (last visited Oct. 16, 2012). See also FCPA Guide, supra note 53, at 71 .

157. See Bristol-Myers Squibb Deferred Prosecution Agreement, at 5-6 (June 13, 2005), available at http://lib.law.virginia.edu/Garrett/prosecution_agreements/pdf/bristol-meyers.pdf; see also WeISSMANN ET AL., supra note 50, at 13-14; Candace Zierdt \& Ellen S. Podgor, Corporate Deferred Prosecutions Through the Looking Glass of Contract Policing, 96 KY. L.J. I, 1 (2007-2008) (outlining different terms found within DPAs and NPAs).

158. See Hasnas, supra note 151 , at 1 .

159. See White, supra note 147 , at 818 (stating that prosecutors have become "super-regulators").

160. See Arlen, supra note 136, at 76 (describing the intrusion of prosecutors into the authority of the corporation to run its business).

161. See Rachel E. Barkow, The Prosecutor as Regulatory Agency, in ProseCUTORS IN THE BOARDROOM: USING CRIMINAL LAW TO REGULATE CORPORATE CONDUCT, supra note 136, at 177; see also Sara Sun Beale, What Are the Rules if Everybody Wants to Play? Multiple Federal and State Prosecutors (Acting) as Regulators, in PROSECUTORS IN THE BOARDROOM: USING CRIMINAL LAW TO REGULATE CORPORATE CONDUCT, supra note 136, at 202 (discussing the extent of prosecutorial leverage and the ability to negotiate quick settlements). 
these agreements, they do not undergo the rigorous cost-benefit analysis of agency-instituted regulations that are required by law. ${ }^{162}$

Prosecutors offering DPAs also act as de facto adjudicators. ${ }^{163}$ Because corporate defendants cannot afford the financial and reputational costs and risks of a jury trial, the prosecutor essentially imposes sentences through a DPA or an NPA. ${ }^{164}$ Additionally, although DPAs and NPAs contain policy changes that can affect the organization at issue or, by extension, the entire industry, courts generally do not scrutinize these changes for abuses. ${ }^{165}$ Because the firm and the DOJ may reach an agreement before an indictment, a judge may never see the agreement and therefore cannot question the firm regarding its understanding of its waiver of rights for the firm or its employees. ${ }^{166}$

Additionally, the DOJ retains absolute discretion as to whether the firm has violated the agreement, an issue that is often not subject to judicial review. ${ }^{167}$ Thus, companies must determine whether they are exposing their executives to individual liability, particularly under the FCPA. ${ }^{168}$

Although the use of DPAs and NPAs forestalls the potentially ruinous effects of a guilty plea or a trial, the agreements may not provide justice. ${ }^{169}$ They may lead to under-enforcement, for example, if a truly culpable firm

162. See Miriam Hechter Baer, Governing Corporate Compliance, 50 B.C. L. REV. 949, 977 (2009); see also Brandon L. Garrett, Structural Reform Prosecution, 93 VA. L. REV. 853, 858 (2007).

163. See Barkow, supra note 161 , at 178 .

164. See id. at $\mathbf{1 7 9}$ (noting that the vicarious liability standard makes the threshold so low that prosecutors can easily obtain indictments and prevail at trial, which induces corporate defendants to plead guilty); see also ERC REPORT, supra note 12, at 35, 51 (arguing that prosecutors have immense leverage in negotiating a DPA because companies want to avoid the consequences of criminal conviction).

165. See Barkow, supra note 161, at 195-96; see also U.S. DEP'T OF JUSTICE, U.S. ATTORNEYS' MANUAL, tit. 9, ch. 9-28.200.B cmt. (General Considerations of Corporate Liability) (1997 rev., as amended) [hereinafter USAM], available at http://www.justice.gov /usao/eousa/foia_reading_room/usam/title $9 / 28 \mathrm{mcrm} . \mathrm{htm}$ (indicating that "[f]or instance, corporations are likely to take immediate remedial steps when one is indicted for criminal misconduct that is pervasive throughout a particular industry, and thus an indictment can provide a unique opportunity for deterrence on a broad scale"); Zierdt \& Podgor, supra note 157, at 1 (noting that "there is no recognition of established policing mechanisms developed by the courts to oversee the agreements reached by the parties to a contract" (footnote omitted)). But see V.S. Khanna, Corporate Liability Standards: When Should Corporations Be Held Criminally Liable?, 37 AM. CRIM. L. REV. 1239, 1271-72 (2000) (questioning whether courts and prosecutors are qualified to assess the effectiveness of a compliance program and suggesting that corporations have an incentive to create "window dressing" compliance programs while still engaging in criminal activity).

166. See Zierdt \& Podgor, supra note 157 , at 14-15.

167. See id.

168. See infra note 188.

169. See supra note 152 and accompanying text. 
knows that it can negotiate an agreement. ${ }^{170}$ However, more often than not, merely negligent firms, or those with rogue employees, feel that they have no other option but to enter into the onerous agreements. ${ }^{171}$

\section{B. An Overview of the Role of Compliance Programs and the Sentencing Guidelines}

The Sentencing Reform Act of 1984 established the U.S. Sentencing Commission (Commission) and charged the Commission with creating binding rules to govern criminal sentences in federal court. ${ }^{172}$ Before this legislation, Congress was concerned that individual judges were making sentencing

170. For example, Massey Energy had the worst mining disaster in 40 years in which twenty-nine employees were killed, and the DOJ still allowed for an NPA. David M. Uhlmann, For 29 Dead Minors, No Justice, N.Y. TIMES, Dec. 9, 2011, at A25. Massey's new owner, Alpha Natural Resources, agreed to pay $\$ 210$ million in fines to the government, compensation to the families of the deceased miners, and safety improvements (much of which was tax-deductible). Alpha Natural Resources, Inc. Non-Prosecution Agreement, at 2-5 (Dec. 6, 2011) available at http:/www.justice.gov/usao/wvs/press_releases/December2011/attachments/Alpha_agreement. pdf; see also Uhlmann, supra, at A25 (explaining that, of the \$209 million settlement, "\$174 million is likely to be tax deductible"). The government's 972-page report concluded that the root cause was Massey's intentional efforts to conceal life-threatening safety violations. See id. Massey's wrongful actions included: maintaining a doctored set of safety records for investigators, intimidating workers who complained of safety issues, warning miners when inspectors were coming (an illegal act), and having an overall record of 370 violations. Id. However, the company itself has escaped prosecution for violations of the Mine Safety and Health Act as well as prosecution for conspiracy and obstruction of justice. Id. Compare that agreement with the Johnson \& Johnson Deferred Prosecution Agreement in which the company agreed to pay $\$ 70$ million in fines and restitution, among other things, for bribery committed by its subsidiaries and partners. See Johnson \& Johnson DPA, supra note 35 (agreeing to pay $\$ 21.4$ million in fines); see also Press Release, Dep't of Justice Office of Pub. Affairs, Johnson \& Johnson Agrees to Pay \$21.4 Million Criminal Penalty to Resolve Foreign Corrupt Practices Act and Oil for Food Investigations (Apr. 8, 2011), available at http://www.justice.gov/opa/pr/2011/April/11-crm

$-446 . h t m l$ (stating that Johnson \& Johnson also agreed to "\$48.6 million in disgorgement of profits," resulting in $\$ 70$ million in total penalties).

171. See, e.g., Weissmann with Newman, supra note 54, at 414 (arguing that a company is rendered unable to defend itself even if it already implemented the controls and measures the government wishes to impose); see also WEISSMANN ET AL., supra note 50, at 2; Jacqueline C. Wolff \& Pamela Sawhney, FCPA Voluntary Disclosures: A Risk/Benefit Analysis, CovINGTON \& BURLING L.L.P., 2008, at 4, available at http:/www.cov.com/files/Publication/97ca6c31-614b -4ace-a441-6dab61135c65/Presentation/PublicationAttachment/3980bda8-c3b1-4f62-9df9-7845d 53e1764/FCPA\%20Voluntary\%20Disclosures\%20-\%20A\%20Risk-Benefit $\% 20$

Analysis.pdf (noting that "[i]f a good corporate citizen discovers a breach of that [FCPA] integrity, voluntarily discloses that breach, and takes significant corrective action to regain the trust of the market, it should not be penalized by greater government scrutiny than it would have had it kept quiet").

172. Sentencing Reform Act of 1984, Pub. L. No. 98-473, 98 Stat. 1987 (codified at 18 U.S.C. $\$ \S 3551-3742(2006)$ and 28 U.S.C. $\$ \S 991-998(2006)$ ). 
determinations based on their own background, experience, and prejudices; therefore, Congress wanted to inject consistency into the process. ${ }^{173}$

In 1991, the Commission added Chapter Eight for organizational defendants, which includes corporations, partnerships, labor unions, pension funds, trusts, nonprofits, and governments. ${ }^{174}$ The Commission recognized the prevailing legal view of vicarious corporate liability but wanted to reward diligence and internal policing by corporate defendants. ${ }^{175}$

The Guidelines use a carrot-and-stick approach intended to incentivize corporations into developing programs designed to deter and detect illegal and unethical conduct. ${ }^{176}$ In theory, the reduction of fines for having a compliance program (the carrot) would lead to less pain from the enhanced penalties (the stick). ${ }^{177}$

173. In the years leading up to the passage of the Sentencing Reform Act, the "unfettered discretion" of judges in determining sentences was one of the main reasons Congress called for sentencing reform. See, e.g., H.R. Rep. No. 98-1017, at 252 (1984) (providing the dissenting views of several representatives who noted a sentencing disparity of "truly alarming proportions"); see also Tania Brief \& Terrell McSweeny, Corporate Criminal Liability, 40 AM. CRIM. L. REv. 337, 348 (2003) (discussing inconsistencies in the application of criminal laws and penalties before the Guidelines).

174. See U.S. SENTENCING GUIDELINES MANUAL $\$ 8$ Al.1 cmt. n.1 (2004) (defining "organizations").

175. Keith Ward \& L.K. Smith, The Federal 'Organizational' Sentencing Guidelines and the Mandate for Compliance Programs: What Civil Practitioners Should Know About Federal Criminal Law, 66 OKLA. B.J. 1725, 1729, 1734 (1995).

176. Id. at 1729. The Guidelines took a cue from the Defense Industry Initiative (DII) in the mid-1980s after the "Ill Winds" procurement scandal, a two-year FBI investigation into fraud and bribery that involved government officials and contractors. This scandal led to the Procurement Integrity Act. See 48 C.F.R. $\$ 3.104$ (1989); see also Ed Magnuson et al., The Pentagon Up for Sale, TIME, June 27, 1988, at 16. The DII promoted development of ethics and compliance programs in response to the 1986 Interim Report of the Packard Commission after the scandal. See Origins of DII, DEFENSE INDUSTRY INITIATIVE, available at http://www.dii.org/about -us/history (last visited Oct. 18, 2012). The Guidelines also built on initiatives in various compliance risk areas. See JAY A. SigLER \& JOSEPH E. MURPHY, INTERACTIVE CORPORATE COMPLIANCE: AN ALTERNATIVE TO REgULATORY COMPULSION 57-61 (1988) (discussing industry initiatives, such as educational and control programs, instituted to comply with communications regulations as well as the efficacy of the "self-reporting" mode of compliance in areas like environmental regulatory compliance). Internal compliance programs started seriously in the 1950s and 1960s after a series of antitrust cases caused the electrical-generating equipment industry to establish programs. See Walsh \& Pyrich, supra note 51 , at 650 .

177. ERC REPORT, supra note 12, at 16 . Federal judges were bound by the Commission's Guidelines until the Supreme Court invalidated mandatory upward departures. United States v. Booker, 543 U.S. 220, 245-46 (2005). Courts still consider the Guidelines when sentencing convicted defendants. See, e.g., United States v. Russell, 564 F.3d 200, 206 (3d Cir. 2009). The DOJ settlement agreements are based, in part, on factors present in the Guidelines. See United States v. Hughley, 193 Fed. App'x 447, 453-54 (6th Cir. 2006) (concluding that a district court judge permissibly engaged in factfinding during a defendant's sentencing when he did so based on his view that the Guidelines were advisory); see also ERC REPORT, supra note 12, at 39 (finding that the district court's interpretation of the Guidelines as advisory was inappropriate). 
Courts determine a corporation's sentence by considering "the seriousness of the offense and the culpability of the organization."178 A corporation with a high culpability score could experience a fine increase of up to eighty times the base fine, while a corporation with a low score could have its fine reduced by ninety-five percent. ${ }^{179}$ To determine the seriousness of the crime, courts first refer to the "offense level[s]" in the Individual Sentencing Guidelines. ${ }^{180}$ This base fine calculation is adjusted up or down based upon the corporation's "culpability score," determined by asking whether:

(1) the organization's top management "participated in, condoned, or was willfully ignorant of the offense;"

(2) "tolerance" of the offense by middle management was "pervasive throughout the organization;"

(3) the organization has a history of criminal convictions or regulatory violations;

(4) the organization obstructed justice or violated specific court orders;

(5) the organization had an effective compliance and ethics program in place;

(6) the organization reported the offense before any imminent threat of disclosure of government investigation;

(7) the organization "fully cooperated in the investigation"; and

(8) the organization "demonstrated recognition and affirmative acceptance of responsibility for its criminal conduct."181

Beginning in 1991, the Commission set out factors for an "effective compliance program," dramatically affecting how corporations use their resources and leading to an increased number of compliance programs. ${ }^{182}$ In fact, "the Guidelines' standards have become the primary reference point . . . in designing corporate compliance/ethics programs." 183

The Commission revised the Guidelines for Organizations most recently in 2004 and 2010. ${ }^{184}$ The first overhaul occurred after Congress passed the Sarbanes-Oxley Act, which required the Commission to review the Guidelines

178. U.S. SENTENCING GUIDELINES MANUAL ch. 8, introductory cmt. (2004) (establishing the purpose behind Chapter 8 as providing "just punishment, adequate deterrence, and incentives for organizations to maintain internal mechanisms for preventing, detecting, and reporting criminal conduct').

179. ERC REPORT, supra note 12, at 22.

180. Ward \& Smith, supra note 175, at 1731.

181. U.S. SENTENCING GUIDELINES MANUAL \& 8C2.3-.5.

182. See ERC REPORT, supra note 12, at 22-24.

183. See id. at 71.

184. See id. at 72 . 
to ensure their sufficiency in deterring and punishing criminal conduct. ${ }^{185}$ The 2004 Amendments "stressed the need for committing adequate resources and providing sufficient authority to the individuals responsible for compliance; suggested new training, monitoring, and program evaluation requirements; and said organizations should establish a mechanism for anonymous reporting of misconduct."186

The 2010 revisions, although not mandatory, added important clarifications. ${ }^{187}$ Significantly, the 2010 Amendments addressed the credit-blocker language in the earlier versions of the Guidelines and now allows for credit even when high-level managers, or those with substantial authority, are involved in the wrongdoing when certain conditions are met. ${ }^{188}$

Ironically, Dodd-Frank, which allows whistleblowers to proceed directly to the SEC, squarely contradicts the intent of the revised Guidelines. ${ }^{189}$ The person with the information has a self-interest in going to the SEC rather than providing the information to the company. ${ }^{190}$ Again, responsible corporations that have adequately staffed and funded their compliance programs are discouraged from investing more in their programs. ${ }^{191}$ Companies that have under-invested or not invested in compliance programs at all now have even less incentive to do so. ${ }^{192}$ Adding to the disincentives, each government enforcement agency, ${ }^{193}$ and sometimes the divisions within those agencies,

185. Sarbanes-Oxley Act of 2002, Pub. L. No. 107-204, 116 Stat. 745 (codified at 15 U.S.C. $\S \S 7201-7266$ (2006)).

186. ERC REPORT, supra note 12, at 26-27 (citing U.S. SENTENCING GUIDELINES MANUAL $\S 8 \mathrm{~B} 2.1(2004))$.

187. Id. at 27.

188. Id. at 27-28. Boards have had oversight responsibility for compliance since In re Caremark International, Inc. Derivative Litigation. 698 A.2d 959, 970 (Del. Ch. 1996) (finding that corporate directors may be exposed to personal liability for failing to adequately monitor employee-wrongdoers; in order to receive business judgment rule protection, directors must "exercise a good faith judgment that the corporation's information and reporting system is in concept and design adequate to assure the board that appropriate information will come to its attention in a timely manner as a matter of ordinary operations").

189. See Legislative Proposals Hearing, supra note 43, at 7-8.

190. See id.

191. See id. (noting that "there are a number of issues" with the law).

192. See id. at 8 (prepared statement of Marcia Narine, witness on behalf of the U.S. Chamber of Commerce) (noting that the irresponsible companies that do not have effective compliance programs or strong ethical cultures "won't have any incentives to develop them now because they will simply assume that employees will report externally"). Similarly, the ERC observed that "Congress should avoid legislation that unintentionally undermines the FSGO or organizational compliance efforts .... [P] oorly drafted whistleblower provisions or other reward programs designed to encourage reporting of misconduct can erode ... programs by encouraging reporting outside the company as a first resort." ERC REPORT, supra note 12, at 12.

193. The following is a non-exhaustive list of agencies that regulate corporate conduct: Commodity Futures Trading Commission, Department of Agriculture, Department of Commerce, Department of Defense, Department of Energy, Department of Health and Human Services, Department of Justice, Department of Labor, Department of Treasury, Environmental Protection 
value compliance programs differently; some rely on the Guidelines while others do not. $^{194}$

Although the Guidelines were designed to provide standards for judges and parameters for companies, in practice, they have been less effective than anticipated. $^{195}$ In May 2012, the Ethics Resource Center (ERC), released a report analyzing the impact and obstacles of the Guidelines and effectiveness of compliance programs as factors in reducing fines and penalties in prosecutions. ${ }^{196}$ The ERC's survey of academics, compliance officers, and general counsel revealed a number of key deficiencies in the functioning of the Guidelines. ${ }^{197}$ First, very few companies receive adequate credit for compliance programs. Since 1991, judges have sentenced 3,433 organizations but only five have received credit for a compliance program according to the U.S. Sentencing Commission. ${ }^{198}$ Although little public information is available, it is likely that those companies that were sentenced were smaller corporations. Of note, the ERC found a lack of cases involving large

Agency, Equal Employment Opportunity Commission, Federal Aviation Administration, Federal Communications Commission, Federal Deposit Insurance Corporation, Federal Energy Regulatory Commission, Federal Reserve Board of Governors, Federal Trade Commission, Food and Drug Administration, General Services Administration, Internal Revenue Service, National Labor Relations Board, Nuclear Regulatory Commission, Securities and Exchange Commission, U.S. Agency for International Development, and U.S. Postal Service. See ERC REPORT, supra note 12, at 55. Depending on the industry, most generic public companies are also subject to the following rules (which may overlap with others): Bureau of Information and Security of the Department of Commerce Export Management and Compliance Program Guidelines, EPA Incentives for Self-Policing Policy, FCPA compliance program requirements imposed by DOJ in recent DPAs, Federal Acquisition Regulation contractor requirements, Federal Sentencing Guidelines Criteria, NYSE Corporate Governance Listing Standard Requirements, Sarbanes-Oxley Act requirements (including COSO Internal Control Framework), and OSHA's Voluntary Safety and Health Program Management Guidelines. Id. at 57-58.

194. Id. at 4. For example, the DOJ Antitrust Division-the only division of the DOJ not bound by the compliance program portion of the U.S. Attorneys' Manual-will not give any credit to a company's compliance program even if it is of excellent quality. Id. at 49 (referring to an August 2011 telephone interview with antitrust division officials). The Guidelines also have a carve-out that, thus far, has not resulted in any company receiving credit for a compliance program in an antitrust case. Id. at $47 \mathrm{n} .106$. Traditionally, the Antitrust Division has focused on the Leniency Program, in which the first company to report collusion and cooperate can avoid prosecution, but it is not required to have a program when it enters the Leniency Program, nor to adopt one as a condition to leniency. Id at 49; see also DEP'T OF JUSTICE, CORPORATE LENIENCY POLICY 2-3 (1993). This leaves companies with less incentive to have or enhance their antitrust programs.

195. See ERC REPORT, supra note 12, at 3 (addressing the challenges of the Guidelines).

196. See id. at 16. In 2012, the ERC provided a list of recommendations to the Sentencing Commission, the Department of Justice, Congress, and the President. See id. at 7.

197. See id. at 3-6. This Article focuses only on those challenges that are relevant to the establishment of a defense.

198. See id. at 37 (citing U.S. SENTENCING COMMISSION, FY 1992-FY 2007). 
companies because many criminal suits were detoured around judges and the courts through the use of DPAs and NPAs. ${ }^{199}$

In addition, despite the significant resources that companies have devoted to compliance programs, there is little evidence that organizations receive adequate consideration for their programs. ${ }^{200}$ In fact, a 2009 Conference Board study confirmed that the DOJ rarely gave credit to or even assessed compliance programs when settling with companies. ${ }^{201}$

The 2012 joint DOJ/SEC Resource Guide to the U.S. Foreign Corrupt Practices Act indicates that the government has no "formulaic requirements" regarding compliance programs and uses a "common sense" and "pragmatic" approach asking "three basic questions:" 1) whether the program was "well designed," 2) whether it was "applied in good faith," and 3) whether it "worked." 202 Unfortunately, although the Guide discusses compliance programs for several pages, citing, among other things, the best practices described in other publications such as the Sentencing Guidelines and other international benchmarks, it provides no specifics on how much credit DOJ offers for compliance programs. The long overdue discussion on compliance programs from DOJ is welcome but does not provide the level of certainty for the business community that is needed for optimal investment, especially because companies can still face the prospect of DPAs and NPAs with a pre-existing compliance program in place. ${ }^{203}$

Moreover, because prosecutors have wide discretion to dispose of cases through DPAs and NPAs, the ERC recommends that judges assert their authority to review settlement agreements filed with the court to confirm that the Guidelines were considered and to challenge the use of other, extraneous criteria. ${ }^{204}$

This Article goes further and argues that prosecutors should bear the burden of rebutting the presumption of an affirmative defense and that the court should play a critical role early in the proceeding by ruling on the defense. The current state of affairs runs afoul of the original legislative intent. ${ }^{205}$ The legislative history reveals Congress's concern about prosecutorial leverage and the role of the courts in examining plea agreements. ${ }^{206}$ In addition, research

199. See id. at 3-4.

200. See id. at 3.

201. Ronald E. Berenbeim \& Jeffrey M. Kaplan, Ethics and Compliance Enforcement Decisions-The Information Gap, WALL STREET LAW., Oct. 2009, at 9, 11; see also ERC REPORT, supra note 12, at 3.

202. See FCPA Guide, supra note 53 , at 56.

203. See infra notes 270,322 and accompanying text.

204. See ERC REPORT, supra note 12, at 97-98.

205. See id. at 51-53 (quoting S. REP. NO. 98-225, at 63 (1983)).

206. See id. at 51-52. 
shows that disclosures to the government may actually harm rather than help the company. ${ }^{207}$ For these reasons, an affirmative defense is necessary. ${ }^{208}$

\section{A PILOT FOR AN AFFIRMATIVE DEFENSE}

\section{A. The Foreign Corrupt Practices Act}

One of the most difficult laws for firms to comply with and, thus, one of the most frequently prosecuted is the FCPA. ${ }^{209}$ Under the FCPA, the DOJ has both criminal and civil enforcement authority and the SEC has civil enforcement authority. ${ }^{210}$ In criminal cases, firms rarely go to trial or even face indictment; rather, firms hope for DPAs or NPAs. ${ }^{211}$ Prosecutors have stated publicly and repeatedly that FCPA enforcement is a priority. ${ }^{212}$

The FCPA has two main provisions. First, it prohibits bribery of foreign officials. ${ }^{213}$ Second, it requires companies to keep accurate books and

207. See Files, supra note 118, at 2-3.

208. See supra notes 205-07.

209. Foreign Corrupt Practices Act of 1977, Pub. L. No. 95-213, 91 Stat. 1494 (codified as amended at 15 U.S.C. $\$ \S 78 \mathrm{~m}(\mathrm{~b}),(\mathrm{d})(1),(\mathrm{g})-(\mathrm{h}), 78 \mathrm{dd}(1)-(3)$, 78ff (2006)). The House Judiciary Committee held hearings on potential amendments to the FCPA and the costs to U.S. businesses for complying, including competitive issues. See FCPA Hearing, supra note 147, at 3-7; see also WEISSMANN \& SMITH, supra note 147, at 2 (noting that the top ten FCPA settlements amount to $\$ 2.8$ billion, all occurring since 2007 , and there are currently more FCPA investigations pending than at any other time since the law's inception); Press Release, Dep't of Justice Office of Pub. Affairs, Department of Justice Secures More Than \$2 Billion in Judgments and Settlements as a Result of Enforcement Actions Led by the Criminal Division (Jan. 21, 2011) [hereinafter DOJ Secures $\$ 2$ Billion] available at http://www.justice.gov/opa/pr/2011/January 111-crm-085.html.

210. Mike Koehler, The Façade of FCPA Enforcement, 41 GEO. J. INT'L L. 907, 923-24 (2010); see also FCPA Guide, supra note 53, at 13.

211. See FCPA Hearing, supra note 147, at 1-2 (statement of Hon. F. James Sensenbrenner, Jr., Chairman, Subcomm. on Crime, Terrorism, and Homeland Security) (stating, "[b]ecause the risks of prosecution are so great, with million-dollar fines and possible prison sentences, companies would rather settle with the Justice Department than go to court. The result is a shortage of court decisions determining the limits of the law."); see also Kevin M. King \& William M. Sullivan, Vigorous FCPA Enforcement Reflects Pursuit of Foreign Bribery, NEW ENGLAND IN-HOUSE (Mar. 2008), http://www.lawyersweekly.com/reprints/fcpaenforcement.htm (providing that seven of the eleven FCPA enforcement actions in 2007 were resolved entirely though a DPA or an NPA); Koehler, supra note 210 , at 908 (observing that privately negotiated settlements with the government "have come to represent de facto FCPA case law").

212. See Robert Khuzami, Dir., Div. of Enforcement, Sec. \& Exch. Comm'n, Remarks Before the New York City Bar: My First 100 Days as Director of Enforcement (Aug. 5, 2009), available at http://www.sec.gov/news/speech/2009/spch080509rk.htm (noting that "[ $\mathrm{t}]$ he Foreign Corrupt Practices Act unit will focus on new and proactive approaches to identifying violations of the Foreign Corrupt Practice Act ... [ [w] hile we have been active in this area, more needs to be done, including being more proactive in investigations, working more closely with our foreign counterparts, and taking a more global approach to these violations").

213. 15 U.S.C. $\$ 78 d d-1$ (a) (2006). 
records. ${ }^{214}$ Often when the government cannot prove a violation of the bribery provisions, it penalizes the company under the books and records provision. ${ }^{215}$ FCPA violations result in serious consequences for companies and individuals. For criminal violations of the bribery provision, corporations can be liable for up to $\$ 2,000,000$ in fines, and individuals are subject for up to $\$ 100,000$ in fines and five years of imprisonment. ${ }^{216}$ FCPA fines may be increased to twice the gross financial gain or loss resulting from the corrupt payment. ${ }^{217}$ For example, in 2009 , the average fine paid was 58.6 million dollars. ${ }^{218}$

Internal investigations can take several months and cost millions of dollars, but companies have no choice if they hope to avail themselves of leniency under either a DPA or an NPA. ${ }^{219}$ Further, the FCPA exposes firms to private civil litigation because shareholders may file securities class action lawsuits alleging that they were harmed by the directors' and officers' failure to comply with the law. ${ }^{220}$ Even when the DOJ agrees to an NPA, these may become a matter of public record and can still lead to shareholder suits with multi-million dollar settlements. ${ }^{221}$

A recent study of FCPA cases between 2002 and 2009 indicates that there is no tangible benefit for voluntary disclosure to the government. ${ }^{222}$ In fact, companies that voluntarily disclose may face a disproportionately larger fine, compared to those companies that do not disclose. ${ }^{223}$ Nevertheless, sixty-four percent of the enforcement actions in 2006 and 2007 stemmed from voluntary disclosures. $^{224}$

214. 15 U.S.C. $\$ 78 \mathrm{~m}(\mathrm{~b})(2)(A)$ (2006).

215. See SEC v. World-Wide Coin Inv., Ltd., 567 F. Supp. 724, 752 (N.D. Ga. 1983) (determining that the company's lax and incomplete record-keeping practices were sufficient as grounds for prosecution under the FCPA).

216. 15 U.S.C. $\$ 78 f f(c)(2006)$.

217. See 18 U.S.C. $\$ 3571$ (d) (2006).

218. See FCPA Winter Review 2010, supra note 24.

219. See FCPA Hearing, supra note 147, at $39 \mathrm{n} .1$ (prepared statement of George J. Terwilliger, III, Partner, White \& Case LLP) (noting that Avon Products "reported in its quarterly filing in February that the company spent $\$ 59$ million in 2009 and $\$ 96$ million in 2010 on 'professional and related fees associated with [its] FCPA investigation and compliance reviews' .... Siemens AG[] spent approximately $\$ 850$ million in legal and accounting fees during the course of a 2 year investigation and Daimler AG] spent approximately $\$ 500$ million in legal and accounting fees during the course of a 5 year investigation" (internal citations omitted)).

220. See, e.g., Freuler v. Parker, 803 F. Supp. 2d 630, 633-34 (S.D. Tex. 2011).

221. See Wolff \& Sawhney, supra note 171, at 3. For example, Titan Industries paid $\$ 61.5$ million to settle a shareholder's suit after entering into an NPA. Stipulation of Settlement at 34, In re Titan Inc. Sec. Litig., No. 04-0676 (S.D. Cal. Sept. 27, 2005).

222. Bruce Hinchey, Punishing the Penitent: Disproportionate Fines in Recent FCPA Enforcements and Suggested Improvements, 40 PUB. CONT. L.J. 393, 397, 415 (2011).

223. See id. at 397-98 (providing an example of a case in which voluntary disclosure led to disproportionate fines).

224. Wolff \& Sawhney, supra note 171, at 1. 
Although some companies purposely engage in wide-scale bribery, ${ }^{225}$ most companies that violate the FCPA do so either unknowingly or unwillingly in order to navigate business in a foreign land. ${ }^{226}$ The reality is that, in many countries, officials and low-level functionaries require and expect bribes regardless of the law. ${ }^{227}$ In many countries it is impossible, either by law or in practice, to do business without an agent or a joint-venture partner. ${ }^{228}$ These agents and partners may subject the firm to liability, especially if the firm is unaware of the agent's or partner's practices, despite the firm's good-faith effort to monitor the person's behavior. ${ }^{229}$

Although the FCPA currently has two affirmative defenses-the local law and the promotional expenses defenses ${ }^{230}$ - some argue that these defenses are illusory. ${ }^{231}$ Many companies look for guidance using the Attorney General's

225. For example, Siemens corporation was subject to over $\$ 900$ million in fines and penalties resulting from payments of slightly under $\$ 1.4$ billion in bribes to governmental entities around the world. Department's Sentencing Memorandum at 5, 25, United States v. Siemens Aktiengesellschaft, No. 08-CR-367-RJL (D.D.C. Dec. 12, 2008), available at http://www.justice.gov/opa/documents/siemens-sentencing-memo.pdf. The executive team, including the legal counsel and internal auditors, was accused of knowing and even participating in the activity. Id. at 22 . The fine was well below what the Guidelines would require even though Siemens did not voluntarily disclose because of the "extraordinary cooperation" and remedial efforts by the Company. Id. at 3.

226. See Koehler, supra note 210 , at $972-75$.

227. See, e.g., Koehler supra note 28, at 620 (observing that "companies seeking to do business in many foreign countries are often funneled into an arbitrary world of low-paying civil servants who frequently supplement their meager salaries through [bribe] payments condoned in the host country" and proposing a defense in which a firm's pre-existing compliance policies and procedures and good-faith efforts are incorporated into the FCPA as an element of a bribery offense).

228. See Sanjiv K. Kapur, Comment, Structuring and Negotiating International Joint Ventures: Anecdotal Evidence from a Large Law Firm Practice, 53 CREIGHTON L. REV. 937,939 (2003) (discussing the benefits of a joint-venture partner).

229. See 15 U.S.C. \$ 78dd-1(a)(3) (2006); see also Jennifer Dawn Taylor, Comment, Ambiguities in the Foreign Corrupt Practices Act: Unnecessary Costs of Fighting Corruption?, 61 LA. L. REV. 861, 871-72 (2001). Despite even the best training and internal controls, employees can run afoul of the laws. In April 2011, the DOJ declined to prosecute Morgan Stanley after its Managing Director pleaded guilty for his role in evading the company's internal controls system in order to enrich himself and a Chinese government official. See Press Release, Dep't of Justice Office of Pub. Affairs, Former Morgan Stanley Managing Director Pleads Guilty for Role in Evading Internal Controls Required by FCPA (Apr. 25, 2012), available at http:/www.justice.gov/opa/pr/2012/April/12-crm-534.html. Although the DOJ praised Morgan Stanley's cooperation and compliance program, most scholars do not believe that the declination was, in fact, the DOJ's recognition of an adequate compliance program defense. See id. Rather, the press release focused on the internal accounting controls rather than the elements of the effective compliance program, and, because of the blatant conspiracy in which the director, the Chinese official, and a Canadian lawyer sought to evade the controls, it is unlikely that any theory of respondeat superior could have attached. See id.

230. 15 U.S.C. $\$ 78 d d-1(c)$.

231. See H.R. REP. No. 100-576, at 922 (1988); see also Kyle P. Sheahen, I'm Not Going to Disneyland: Illusory Affirmative Defenses Under the Foreign Corrupt Practices Act, 28 WISC. 
Review Opinion Procedure, ${ }^{232}$ which enables concerned parties to determine "whether certain specified, prospective-not hypothetical-conduct conforms to the [DOJ]'s present enforcement policy regarding the anti-bribery provisions of the [FCPA]."233 However, the Opinion Procedure provides no guarantees to the non-recipient company, is non-binding to the business community, and the prosecutor can still take action against a recipient company if the facts change or the information was incomplete or inaccurate. ${ }^{234}$

\section{B. International Enforcement and Defenses}

Operating in various countries, including the United States, subjects multinational firms to multi-jurisdictional enforcement, often with conflicting rules. $^{235}$ For example, U.S. issuers who do business in the United Kingdom must also comply with the Bribery Act of 2010 (U.K. Act). ${ }^{236}$ Although the U.K. Act reaches further than the FCPA, the law does provide for an affirmative defense for firms with adequate compliance programs. ${ }^{237}$ The U.K. Ministry of Justice has provided the following guidance consisting of six principles for the affirmative defense:

INT'L L.J. 464, 470 (2010) (noting that laws specifically allowing payments to government officials are rare and that, generally, the payments are part of unwritten customs and practices of doing business); Taylor, supra note 229, at 876 (explaining that, because most practices are not authorized by written law, few practices are likely to qualify for the defense). Facilitating payments for routine, nondiscretionary tasks are allowed under 15 U.S.C. $\$ 78 \mathrm{dd}$-2(d)(b); however, only five countries in the world currently allow them: Australia, Canada, South Korea, the United States, and New Zealand. TRACE ANTI-BRIBERY COMPLIANCE SOLUTIONS, TRACE FACILITATIONS PAYMENTS IN BENChMARKNG SURVEY 2 (2009), available at https:/www.traceinternational.org/documents/FacilitationPaymentssurveyResults.pdf. The Organization for Economic Cooperation and Development (OECD) considers these payments bribes and called for a ban on them in November 2009. See WORKING GRP. ON BRIBERY IN INT'L BUS. TRANSACTIONS, OECD, RECOMMENDATION OF THE COUNCIL FOR FURTHER COMBATING BRIBERY OF FOREIGN PUBLIC OFFICIALS IN INTERNATIONAL BUSINESS TRANSACTIONS paras. IV-VII (2009), available at http://www.oecd.org/dataoecd/1// 40/44176910.pdf.

232. 15 U.S.C. $\$ \S 78 \mathrm{dd}-1(\mathrm{e})$ to $-2(\mathrm{f})$ (2006); see also Mike Koehler, Compliance Lessons from an Active Year in FCPA Enforcement, 3 WHITE COLLAR CRIME REP. 116, $118-19$ (2008) (suggesting that "ensuring FCPA corporate compliance is a task best shared by personnel throughout the company" and that executives particularly must comply because "[b]usiness leaders who fail to heed the lessons of 2007's many actions against individuals risk not only FCPA statutory fines and penalties, but also disgorgement of bonus compensation").

233. Foreign Corrupt Practices Act Opinion Procedure, 28 C.F.R. $\S 80.1$ (2011); see also FCPA Guide, supra note 53, at 86-87.

234. See 28 C.F.R. $\$ 80.5, .11$ (2011); see also Sheahen, supra note 231, at 487-88.

235. DAVID KENNEDY \& DAN DANIELSEN, BUSTING BRIBERY: SUSTAINING THE GLOBAL MOMENTUM OF THE FOREIGN CORRUPT PRACTICES ACT 17-24 (2011), available at http://www.opensocietyfoundations.org/sites/default/files/Busting\%2520Bribery201 1September.p df.

236. Bribery Act, 2010, c. $23, \S 7$ (U.K.).

237. Id. $\$ 7(2)$. 
A company must have:

1. regular and comprehensive assessments on bribery-related risks;

2. top-level commitment to preventing bribery;

3. due diligence policies and procedures that cover all business partners;

4. clear, practical and accessible policies and procedures;

5. effective implementation of policies and procedures throughout the organization; and

6. monitoring and reviewing mechanisms to ensure compliance with relevant policies and procedures, and implementation of remedial measures when necessary. ${ }^{238}$

The UK's Serious Fraud Office (SFO) recognized that "[t]he objective of the Act is not to bring the full force of the criminal law to bear upon well run commercial organisations that experience an isolated incident of bribery on their behalf."239 Instead, the SFO will take the existence of a compliance program into account when determining whether to prosecute a corporation, and will decline to prosecute in situations where a company had an effective compliance system but neither detected nor deterred rogue employee or agent activity. ${ }^{240}$ This system provides firms with both an incentive to develop a state-of-the-art compliance program and some negotiating leverage in the event the SFO contemplates bringing charges. ${ }^{241}$

In addition to the United Kingdom, other countries, including Australia, Chile, Germany, Hungary, Italy, Japan, Korea, Poland, Portugal, Sweden, and Switzerland, have comparable defenses to corporate criminal liability for bribery. ${ }^{242}$ In many instances the prosecution bears the burden of proving that the firm failed to adequately supervise its employees. ${ }^{243}$ In varying degrees, these countries allow a due diligence defense as long as there is evidence of

238. U.K. MINISTRY OF JUSTICE, THE BRIBERY ACT 2010: GUIDANCE 20-31 (2010), available at http://www.justice.gov.uk/downloads/legislation/making-reviewing-law/bribery-act -2010-guidance.pdf.

239. Id. at 8.

240. See id. at 15 (demonstrating leniency for corporations that can show that adequate procedures were in place to prevent bribery).

241. See Jon Jordan, Recent Developments in the Foreign Corrupt Practices Act and the New UK Bribery Act: A Global Trend Towards Greater Accountability in the Prevention of Foreign Bribery, 7 N.Y.U. J. L. \& BUS. 845, 869 (2011).

242. See Koehler, supra note 28, at 638-44 (containing a brief description of each country's defense); see also D.Lgs. 8 giugno 2001, n. 231 (It.); MCDERMOTT, WILL \& EMERY, ITALIAN LAW No. 231/2001: AVOIDING LIABILITY FOR CRIMES COMMITTED BY A COMPANY'S REPRESENTATIVES 3 (2009), available at http:/www.mwe.com/info/news/wp0409f.pdf (discussing an affirmative defense for corporate crimes, such as fraud, bribery, and market control).

243. See Koehler, supra note 28, at 640, 644 (noting that, in Chile and Switzerland, the prosecutor bears the burden of proof to show that a company failed to have a sufficient system of management and supervision). 
some level of high managerial action, knowledge, or willful ignorance of the illegal behavior. ${ }^{244}$

The standards set out by the United Kingdom and other countries are strikingly similar to what the Guidelines already provide for mitigating credit. ${ }^{245}$ These European models delay criminal liability, whereas in the United States, firms must wait until the sentencing phase or hope that prosecutors give the program enough credit to reap the benefits of its compliance programs. ${ }^{246}$

The FCPA is a perfect subject for a pilot compliance defense for three reasons. ${ }^{247}$ First, prosecutors have made clear that this is an area of increasing importance. ${ }^{248}$ Additionally, U.S. companies complain that the law's vagueness and enforcement efforts make U.S. companies less competitive around the world. ${ }^{249}$ Second, at least half of the DPAs and NPAs in use relate to the FCPA, and these agreements are rarely subject to rigorous judicial scrutiny. ${ }^{250}$ Third, employees and agents across the world could violate the law without the knowledge or consent of corporate management and rob the firm of a meaningful chance to defend itself. ${ }^{251}$ Ironically, an unscrupulous agent who commits bribery without the company's knowledge could also theoretically collect a whistleblower bounty under Dodd-Frank for reporting the conduct. ${ }^{252}$ For these reasons, Congress must amend the FCPA to allow for

244. See id. at 639-44 (highlighting the defenses of other nations).

245. See U.S. SENTENCING GUIDELINES MANUAL $\S 8 B 2.1$ (2004) (requiring an effective compliance program).

246. See FCPA Hearing, supra note 147, at 19 (statement of the Hon. Michael Mukasey, former Att'y Gen., Partner, Debevoise \& Plimpton, LLP); see also id. at 23-24; Senate FCPA, supra note 27, at 15 (statement of Andrew Weissmann, Partner, Jenner \& Block, LLP).

247. FCPA Hearing, supra note 147, at 3 (statement of Rep. Bobby Scott, Member, Subcomm. on Crime, Terrorism, and Homeland Security) (discussing the importance of an affirmative defense); see also infra notes 248-51 and accompanying text.

248. See FCPA Hearing, supra note 147, at 3 (statement of Rep. Bobby Scott, Member Subcomm. on Crime, Terrorism, and Homeland Security) (discussing the increased number of prosecutions).

249. See id. at 3 (observing that the lack of clear standards and guidance may stifle competitiveness and make companies wary of doing business in certain parts of the world); see also Senate FCPA, supra note 27, at 88 (statement of Andrew Weissmann, Partner, Jenner \& Block, LLP).

250. See Corporate Crime, supra note 138, at 1 (statement of Eileen R. Larence, Director, Homeland Security, U.S. Govemment Accountability Office); see also FCPA Hearing, supra note 147, at 40 (prepared statement of George J. Terwilliger, III, Partner, White \& Case LLP) (noting that federal prosecutors have broad discretion to interpret the FCPA with "prosecutorial common law;" calling for a post-closing period of repose for companies involved in acquisitions during which they would be shielded from FCPA enforcement by a safe-harbor defense for companies with state-of-the-art compliance programs that self-report violations).

251. See FCPA Hearing, supra note 147, at 37, 51-52 (statement of Shana-Tara Regon, Director, White Collar Crime Policy, National Association of Criminal Defense Lawyers).

252. See Whistleblower Incentives and Protection, 76 Fed. Reg. 53,172, 53,191 (Aug. 25, 2011) (codified at 17 C.F.R. pt. 165). As of the time of this Article, the government has not 
an affirmative defense. Currently, a company cannot avail itself of either the local law or promotional expense activity defense, yet it still faces liability because of rogue employees or non-employee agents who choose to ignore well-established company policies and compliance program requirements. ${ }^{253}$ Companies that self-report and cooperate still face criminal liability, which leaves no incentive to work to deter illegal behavior other than the benefit of a lower fine and an onerous DPA or NPA. ${ }^{254}$

Critics of the defense argue that, if a compliance violation occurs, the company's compliance program, by definition, failed to prevent the illegal acts. $^{255}$ However, those critics ignore the harsh impact of respondeat superior on firms with potentially thousands of employees and hundreds of agents or joint venture partners in dozens of countries around the world. ${ }^{256}$ The DOJ itself has conceded that not even the best program can prevent all criminal conduct. $^{257}$

However, the DOJ secures large sums from FCPA enforcement and, therefore, has no reason to cede any of its leverage. ${ }^{258}$ The DOJ opposes a

provided the number of whistleblowers who have used the hotline. Accordingly, it is impossible to know whether employees, agents, competitors, or members of the general public are reporting tips.

253. See FCPA Hearing, supra note 147, at 19, 23 (statement of the Hon. Michael Mukasey, former Att'y Gen., Partner, Debevoise \& Plimpton, LLP). The DOJ stated that it generally does not prosecute cases based on the action of one employee or one payment and that the existence of a compliance program is a significant factor. Id. at 11-12 (prepared statement of George Andres, Acting Deputy Att'y Gen., U.S. Department of Justice Criminal Division); see also Thompson Memorandum, supra note 141, at 5 (noting that, in certain limited circumstances, it may not be appropriate to impose liability on a corporation, particularly one with a compliance program in place, under a strict respondeat superior theory for the isolated act of a rogue employee). However, that argument is a red herring. If a number of agents around the world choose to violate company policy, the firm still faces criminal liability regardless of any good faith efforts to comply. See FCPA Hearing, supra note 147, at 19, 23-26 (statement of the Hon. Michael Mukasey, former Att'y Gen., Partner, Debevoise \& Plimpton, LLP).

254. See FCPA Hearing, supra note 147, at 5 (testimony of the Hon. Michael Mukasey, former Att'y Gen., Partner, Debevoise \& Plimpton, LLP) (stating "the absence of a compliance defense tells corporate America, in effect, no compliance effort can be good enough-even if you did everything we required, we still retain the right to prosecute purely as a matter of our discretion. I question whether that is the appropriate signal to send to the business community and to American shareholders").

255. See Kennedy \& Danielsen, supra note 235 (arguing that an affirmative defense would announce to the world that the United States is wavering in its commitment to global corruption and could stall the efforts of other countries worldwide).

256. See FCPA Hearing, supra note 147, at 37, 52-53 (statement of Shana-Tara Regon, Director, White Collar Crime Policy, National Association of Criminal Defense Lawyers); see also id. at 25 (statement of the Hon. Michael Mukasey, former Att'y Gen., Partner, Debevoise \& Plimpton, LLP).

257. USAM, supra note 165 , ch. 9-28.800 (indicating that "no compliance program can ever prevent all criminal activity by a corporation's employees").

258. Half of all of the fines secured by the DOJ's Criminal Division in 2010 were related to FCPA enforcement actions. See DOJ Secures \$2 Billion, supra note 209. 
defense because, in its view, it already takes into consideration compliance efforts under the Guidelines, and it is also concerned that a defense could allow clever companies to implement paper programs and then hire experts to vouch for them, leading to a so-called "battle of the experts" at enforcement. ${ }^{259}$ This argument, however, fails to recognize that many companies already have paper programs and these companies adopt a "check the box" mentality precisely because there is no guarantee that their program will receive adequate recognition during the negotiation or sentencing process. ${ }^{260}$ The only companies with any level of comfort that their programs can pass muster are those that utilize the Opinion Procedure Release Program, but, even then, there is no guarantee that the DOJ will choose not to prosecute. ${ }^{261}$

More importantly, the defense would not act as a "get out of jail free card."262 Companies that have clearly and repeatedly violated the law with sustained, significant bribes or willful blindness to the possibility of bribes could not avail themselves of the defense. ${ }^{263}$ Companies will conduct their own cost-benefit analysis as to how much to invest in compliance programs. ${ }^{264}$ The DOJ's resources are best served prosecuting those companies that have chosen not to invest in a bona fide, sincere compliance program. ${ }^{265}$

\section{PARAMETERS FOR A NEW AFFIRMATIVE DEFENSE}

\section{A. A Title VII Analogy}

The idea of an affirmative defense for illegal behavior already exists in the civil context. ${ }^{266}$ Companies accused of harassment and discrimination based on their employees' actions have enjoyed the use of affirmative defenses since

259. See Senate FCPA, supra note 27 , at 26.

260. See FCPA Hearing, supra note 147, at 19 (statement of the Hon. Michael Mukasey, former Att'y Gen., Partner, Debevoise \& Plimpton, LLP) (discussing the conflicting incentives for creating compliance programs); see also Khanna, supra note 165, at 1271-72 (discussing "window dressing" compliance programs).

261. See supra notes 232-34 and accompanying text.

262. See FCPA Hearing, supra note 147, at 55 (response of the Hon. Michael Mukasey, former Att'y Gen., Partner, Debevoise \& Plimpton, LLP) (noting that it would be difficult for a company to establish the defense).

263. See Senate FCPA, supra note 27, at 16 (statement of Andrew Weissmann, Partner, Jenner \& Block, LLP) (noting that the defense would not apply to companies with pervasive corruption such as Enron); see also Koehler, supra note 28, at 611 (stating that it would not be an all-inclusive defense and there would still be corporate liability).

264. See FCPA Hearing, supra note 147, at 43 (statement of George J. Terwilliger, III, Partner, White \& Case, LLP) (discussing the cost-benefit analysis currently used by companies).

265. See id. at 43-44 (noting that the government could conserve resources with an increase in self-reporting); see also Koehler, supra note 28, at 658 (arguing that, with a compliance defense, the DOJ could better allocate its prosecutorial resources).

266. See FCPA Hearing, supra note 147, at 19 (statement of the Hon. Michael Mukasey, former Att'y Gen., Partner, Debevoise \& Plimpton, LLP) (comparing the compliance defense to the defense available under Title VII of the Civil Rights Act of 1964). 
the decision in Faragher v. City of Boca Raton. ${ }^{267}$ To prevail under the Faragher defense, as long as no supervisor took a tangible employment action, such as demoting or firing an employee, the company must prove that: (1) "the employer exercised reasonable care to prevent and correct promptly any [discriminatory] harassing behavior" and (2) "the plaintiff employee unreasonably failed to take advantage of any preventive or corrective opportunities provided by the employer or to avoid harm otherwise."268 The affirmative defense requires a fact-specific inquiry, and there is no guarantee that employers will prevail. ${ }^{269}$ However, at least employers have certainty as to the applicable standard and can devote the appropriate level of resources, training, monitoring, and auditing to prevent, detect, and deter wrongdoing. ${ }^{270}$

In the Title VII context, in Kolstad v. American Dental Ass'n, the Supreme Court ruled that companies able to demonstrate specific steps taken to prevent inappropriate behavior should not be burdened with respondeat superior liability for punitive damages. ${ }^{271}$ Significantly, the Court observed that it would be unfair to hold employers vicariously liable for punitive damages where the rogue employee made decisions contrary to the employer's "good-faith efforts to comply with Title VII."272 The Court opined that such liability would "dissuad[e] employers from implementing programs or policies

267. See Faragher v. City of Boca Raton, 524 U.S. 775, 780 (1998) (holding that an employer is vicariously liable for a supervisor's discrimination, but an affirmative defense is available that considers the reasonableness of the employer's and plaintiff's conduct); see also Charles W. Garrison, Comment, Once Is Enough: The Need to Apply the Full Ellerth/Faragher Affirmative Defense in Single Incident and Incipient Hostile Work Environment Claims, 61 CATH. U. L. REV. 1131, 1144 (discussing Faragher's affirmative defense in the context of Title VII hostile work-environment claims).

268. Id. at 807; see also Enforcement Guidance on Vicarious Employer Liability for Unlawful Harassment by Supervisors, EQUAL EMP. OPPORTUNITY COMM'N (June 18, 1999), http://www.eeoc.gov/policy/does/harassment.html [hereinafter Enforcement Guidance] (stating that "[s]uch reasonable care generally requires an employer to establish, disseminate, and enforce an anti-harassment policy and complaint procedure and to take other reasonable steps to prevent and correct harassment"). However, companies that make reasonable efforts to comply with the law still face vicarious liability if the employee uses the reporting mechanisms provided by the company. Id. Nevertheless, the availability of an affirmative defense is a significant incentive for companies to promote the kind of environment in which management would obey the law, thereby eliminating the need for employee complaints. Id.

269. Enforcement Guidance, supra note 268 (noting that whether the compliance system is sufficient requires a factual analysis).

270. See id. (discussing the elements of a compliance system).

271. Kolstad v. Am. Dental Ass'n., 527 U.S. 526, 548 (1999) (holding, in part, that an employer is not responsible for punitive damages where his managerial agent made discriminatory employment decisions if the employer made a good-faith effort to comply with Title VII).

272. Id. (quoting Kolstad v. Am. Dental Ass'n, 139 F.3d 958, 974 (D.C. Cir. 1998) (Tatel, J., dissenting)). 
to prevent discrimination" for fear that such programs would reveal violations for which a company would ultimately be liable. ${ }^{273}$

The same reasoning applies under the FCPA. If the Supreme Court believes that vicarious liability is inappropriate in the context of civil punitive damages and is unnecessary for deterrence, it is logical to conclude that vicarious liability is also inappropriate in the criminal context. ${ }^{274}$

\section{B. Elements of the Enhanced Compliance Program Required to Prevail}

The United States' approach to corporate criminal liability varies from a majority of other countries' approaches. ${ }^{275}$ With an increasingly interconnected global business presence, U.S. companies should not be placed at a disadvantage by having harsher corporate penalties. ${ }^{276}$ The proposed standard builds on the Model Penal Code, the U.K. Bribery Act, and the Faragher and Kolstad Supreme Court decisions, and it expands on some of the existing literature by adding factors for the courts to evaluate when determining whether to impose criminal liability. ${ }^{277}$ The proposed standard also incorporates factors already considered by the DOJ and sentencing judges as mitigating factors but instead elevates them to factors for a defense. ${ }^{278}$

To prevail, the company must prove that it acted reasonably in establishing a compliance program designed to deter, detect, punish, and disclose illegal behavior. ${ }^{279}$ The company must also provide evidence of how the program operated in the particular case at issue (i.e., when and whether the wrongdoers were trained, the kind of incentive plans that could have either led to or discouraged the behavior, the types of auditing and monitoring programs that were in place to detect or deter the behavior, and any self-disclosure). ${ }^{280}$ Prosecutors and courts would assess reasonableness by comparing the company to similarly situated firms. ${ }^{281}$ Generally, because the company could

273. Id.

274. The Supreme Court has repeatedly analogized the goals of punitive damages and criminal liability. See, e.g., Philip Morris v. Williams, 549 U.S. 346, 351-53 (2007); BMW of N. Am. Inc. v. Gore, 517 U.S. 559, 568 (1996) (noting that the purpose of punitive damages is to punish unlawful conduct and deter repetition); United States v. Halper, 490 U.S. 435, 447-48 (1989) (discussing the similar goals of civil and criminal punishments).

275. See Arlen, supra note 116 , at 147 n.13 (noting that other countries restrict liability to crimes by senior managers or allow a good faith defense for an effective compliance program).

276. See FCPA Hearing, supra note 147, at 3 (statement of Rep. Bobby Scott, Member, Subcomm. on Crime, Terrorism, and Homeland Security) (stating that "over-aggressive enforcement" is a disadvantage to American companies).

277. See supra note 51 and accompanying text.

278. See FCPA Hearing, supra note 147, at 19 (statement of the Hon. Michael Mukasey, former Att'y Gen., Partner, Debevoise \& Plimpton, LLP) (arguing for an affirmative defense).

279. See id. at 23 (offering a proposal for a compliance defense).

280. See Senate FCPA, supra note 27 , at 26 ; see also supra note 27 and accompanying text.

281. See supra notes $49-50$ and accompanying text. 
prove at an early stage that it had an effective program in place, the prosecutor would decline prosecution and the matter would never come before a court.

The burden would then shift to the government, which would have to prove that the firm did not have an effective compliance program. ${ }^{282}$ This affirmative defense would apply only when employees had committed misconduct contrary to law, policy, or management instructions. ${ }^{283}$ If the company adopted or ratified the conduct and/or did not correct it, it could not avail itself of the defense. ${ }^{284}$ Companies in which management suffers from "motivated blindness," and "fails to notice others' unethical behavior if it's in [their] interest not to notice" could not use the defense. ${ }^{285}$ This also comports with the current Guidelines' requirement to discipline those who fail to take responsible steps to detect or prevent wrongdoing. ${ }^{286}$

In essence, the company's own action or inaction would provide evidence of its intent to deter and detect criminal activity. ${ }^{287}$ The prosecutor would have to rebut the defense posed by the firm, which would provide evidence that it has:

(1) implemented a state-of-the-art program approved and overseen by the board or a designated board committee, and that the company receives comprehensive updates at least twice yearly from the compliance officer; ${ }^{288}$

(2) elevated the compliance officer to report directly to the board or a designated committee and made the officer terminable only by the board; 289

(3) clearly communicated the corporation's intent to comply with the law and appropriate penalties for prohibited acts to employees,

282. See WEISSMANN ET AL., supra note 50 (providing a discussion of effective compliance programs and the role of sentencing); see also supra note 50 and accompanying text.

283. See supra note 51 and accompanying text.

284. See U.S. SENTENCING GUIDELINES MANUAL § 8B2.1(7) (2004).

285. See Max H. Bazerman \& Ann E. Tenbrunsel, A Lesson from Warren Buffet About Ethical Blindspots, HARVARD BUSINESS REVIEW: HBR BLOG NETWORK (May 31, 2011, 12:15 PM), http://blogs.hbr.org/hbsfaculty/201 1/05/a-lesson-from-warren-buffet-ab.html (observing that "even good people are affected by motivational blindness. A desire for integrity is no protection from conflicts of interest. Creating true objectivity-whether in managerial or organizational decisions-requires eliminating the conflicts of interest that bias judgments"); see also Jeff Kaplan, Behavioral Ethics and Management Accountability for Compliance and Ethics Failures, CONFLICT OF INTEREST BLOG, (Feb. 1, 2012), http://conflictofinterestblog.com /2012/02/behavioral-ethics-and-management-accountability-for-compliance-and-ethics-failures.ht $\mathrm{ml}$ (recommending training of investigators and auditors to ascertain whether "if a manager's being asleep at the switch led to the violation in question").

286. See U.S. SENTENCING GUIDELINES MANUAL § 8C2.5(f).

287. See supra note 51 (reviewing different approaches to show corporate criminal intent).

288. See U.S. SENTENCING GUIDELINES MANUAL § 8B2.1(b); see also FCPA Hearing, supra note 147, at 38 (statement of George J. Terwilliger, HI, Partner, White \& Case, LLP).

289. See ERC REPORT, supra note 12, at 66. 
suppliers, agents, and partners; ${ }^{290}$

(4) developed and provided position-specific annual training on legal and ethical obligations for employees and board members; ${ }^{291}$

(5) met or exceeded industry standards and norms related to compliance and ethics; ${ }^{292}$

(6) provided the appropriate training and policies to agents, joint venture partners, and others with the ability to subject the company to liability, required these parties to comply, received annual compliance certifications, and audited their compliance with the same rigor as it audits the company's own processes; ${ }^{293}$

(7) consistently applied anti-retaliation policies for whistleblowers, including terminating those who engage in retaliation; ${ }^{294}$

(8) not acted as a habitual recidivist, meaning that the company may have had rogue employees in the past, but has learned from the compliance failure rather than continuing the same conduct; ${ }^{295}$

(9) voluntarily reported wrongdoing to authorities when appropriate; ${ }^{296}$

(10) been periodically audited and benchmarked by an independent third party that does not provide any other consulting or professional services to the company or have any actual or perceived conflicts of interest, such as providing legal advice or external auditing similar to that required by Sarbanes-Oxley or for other purposes, and/or is pre-certified by the appropriate U.S. government agency; ${ }^{297}$ and

290. See Walsh \& Pyrich, supra note 51, at 674 (noting that the corporation "must take steps to communicate ... [the compliance] standards to its agents and employees").

291. In their article, Walsh \& Pyrich discuss the role that training should play in compliance programs when corporations are seeking to use evidence of a compliance program to avoid criminal liability. See id. at 647.

292. Regulating industry standards, it is clear that all companies should be treated according to their size and subject to standards that are appropriately scaled to comport with business realities.

293. The Guidelines address the importance of training in an effective compliance program. See U.S. SENTENCING GUIDELINES MANUAL \& 8B2.1(b)(4)(A) (2004) ("The organization shall take reasonable steps to communicate periodically and in a practical manner its standards and procedures ... by conducting effective training programs ....").

294. See supra notes 9-11 (discussing the various laws that protect whistleblowers and prevent retaliation by companies).

295. See U.S. SENTENCING Guidelines MANUAL § 8C2.5(c) (2004).

296. See WEISSMANN ET AL., supra note 50, at 6 (contending that handing out harsh punishments to corporations with effective compliance programs that attempt to uncover and disclose wrongdoings is counter to basic criminal law tenets); see also Wolff \& Sawhney, supra note 171, at 4 (arguing that a corporation that voluntarily discloses wrongdoings should be spared greater punishment than would be given otherwise).

297. See TRACE ANTI-BRIBERY COMPLIANCE SOLUTIONS, supra note 231, at 2. 
(11) made modifications, if necessary, to the compliance program based upon the results of the audit. ${ }^{298}$

The external compliance audit or pre-certification process should benchmark the company to peer companies and the general corporate population, reviewing, at a minimum, the following factors:

(1) the corporate culture and tone throughout the organization; ${ }^{299}$

(2) incentive programs and compensation plans at all levels of the organization that encourage legal, ethical behavior, ${ }^{300}$

(3) promotional practices and the consideration of compliance and ethical behavior before such decisions; ${ }^{301}$

(4) adequacy, timeliness, and comprehensiveness of training initiatives and the level of employee engagement and understanding of their general and specific responsibilities; ${ }^{302}$

(5) the effectiveness of the anti-retaliation programs; ${ }^{303}$

(6) the effectiveness and usage rate of the anonymous reporting mechanisms; ${ }^{304}$

298. See Walsh \& Pyrich, supra note 51, at 688 ("A reasonable[,] diligent compliance program must be periodically reviewed and revised. Compliance programs should be modified and updated to reflect the corporation's ongoing work experience, new developments in the law, or incidents of noncompliance.").

299. See Bucy, supra note 51, at 1099, 1121-23 (asserting that corporations have distinct identities that should be taken into account to mitigate or increase corporate criminal liability). This factor considers the "corporate ethos" theory espoused by Pamela H. Bucy in which a corporation cannot be held liable for its employees' actions unless the corporate culture promoted or condoned the conduct at issue. Id. at 1099. Wal-Mart, which has championed the defense, would not be eligible to claim the defense if the 2012 allegations of bribery, tax evasion, and a senior-level cover-up related to its Mexico operations are true. See Vast Mexico Bribery Case Hushed Up by Wal-Mart After Top-Level Struggle, N.Y. TIMES, Apr. 21, 2012, at A1; see also Samuel Rubenfeld, Lawmakers Allege Wal-Mart 'May Have' Evaded Taxes, Laundered Money, WALL ST. J., Aug. 15, 2012, http://blogs.wsj.com/corruption-currents/2012/08/15/lawmakers -allege-wal-mart-may-have-evaded-taxes-laundered-money/. The higher up the level of the wrongdoer, the higher the burden for the company. This is also the Model Penal Code's approach.

300. See U.S. SENTENCING GuIDELINES MANUAL § 8B2.1(b)(6)(A) (2004). Companies that have financial incentives in place that either encourage unlawful or unethical behavior through goals that are impossible to reach or fail to penalize bad conduct would fail this critical prong, which would disqualify them from using the defense. See Stout, supra note 83, at 2, 8 (applying behavioral science to incentive-based pay and arguing that excessive reliance on even well designed ex-ante incentive plans can "snuff out" or suppress conscience and create "psycopathogenic" environments, and has done so as evidenced by "a disturbing outbreak of executive-driven corporate frauds, scandals and failures").

301. ERC REPORT, supra note 12, at 75 (quoting BEN W. HENEMANN, JR., HIGH PERFORMANCE WITH HIGH INTEGRITY 94-99 (2008)).

302. See U.S. SENTENCING GUIDELINES MANUAL § 8B2.1(b)(4)(A) (2004).

303. Securities Exchange Act of 1934, Pub. L. No. 73-291, $\$ 21 F, 48$ Stat. 881 (codified as amended at 15 U.S.C. $\$ 78 \mathrm{u}-6(2006))$.

304. See U.S. SENTENCING GUIDELINES MANUAL § 8B2.1(b)(5)(C). 
(7) the process by which complaints are investigated, including a random audit of investigations for thoroughness; 305

(8) the adequacy of the resources for the compliance function, including continuing external education, appropriate salaries, and sufficient personnel for the size of the organization and the nature of the risks for the organization and its industry; ${ }^{306}$ and

(9) the level of board engagement and understanding of the company's compliance based on the risks related to its business, geography, employee base, and incentive structures. ${ }^{307}$

Such an audit would only have credibility for the affirmative defense if the auditors had unfettered access to employees, agents, suppliers, board members, executives, and documents. ${ }^{308}$ Notably, incentives or conflicts of interest for the auditing firm may also cloud credibility. ${ }^{309}$ Monetary payments not only corrupt individual employees-they can also corrupt "independent" auditors or law firms, which might have an incentive to provide the kinds of assurances that the company wants in order to obtain additional business. ${ }^{310}$ The new auditors would likely have to come from a stand-alone business that does not provide any services other than consulting on remedial measures to the firm that was audited. ${ }^{311}$ 'If not monitored carefully, this relationship could lead to the sale of unnecessary services to the client firm, but it is still less likely to lead to the kind of conflict that plagued the rating agencies who were paid to review firms and assure Wall Street investors of the viability of those firms. ${ }^{312}$

A preferable option provides a proactive role for the government. ${ }^{313}$ The DOJ or another appropriate agency could accept a fee based upon the size and complexity of the organization to conduct the audit using the factors described

305. See id. §8B2.1(c).

306. See id. \& 8B2.1(b)(2)(C).

307. See id. \$ 8B2.1(b)(4)(A).

308. See supra note 47 and accompanying text.

309. See infra note 312 .

310. See supra note 42 and accompanying text.

311. See supra note 47 and accompanying text.

312. See Rupert Neate, Ratings Agencies Suffer 'Conflict of Interest', Says Former Moody's Boss, THE GUARDIAN (Aug. 22, 2011), http://www.guardian.co.uk/business/2011/aug/22 /ratings-agencies-conflict-of-interest (quoting a former Moody's executive's statement to the SEC that Moody's uses "intimidation and harassment" so that its analysts ensured ratings matched client demands and "rewarded lenient voting"); see also Timothy E. Lynch, Deeply and Persistently Conflicted: Credit Rating Agencies in the Current Regulatory Environment 59 CASE W. L. REV. 227, 230-31 (2009). Dodd-Frank also has rules regarding removing references to the use of rating agencies in its regulations. As of the time of this writing, the rules had not yet been finalized. See Credit Rating Agencies, U.S. SEC. \& EXCHANGE COMM'N, http://www.sec.gov/spotlight/dodd-frank/creditratingagencies.shtml (last visited Oct. 18, 2012).

313. See supra note 212 and accompanying text. 
above. $^{314}$ The same way that the DOJ currently requires companies to augment their compliance programs as part of a DPA or an NPA, compliance programs could be utilized before the company is charged with a crime. ${ }^{315}$ The DOJ and other government agencies could partner with corporations by holding training and certification programs. ${ }^{316}$ The DOJ or other independent entity could build on the Guide or similar publication. If the compliance officer and other relevant officers attend, this could be an additional, significant factor for the affirmative defense. ${ }^{317}$ Of course, if the company veered materially from the pre-certified compliance program, making the program less comprehensive without a valid reason (e.g., the company shed divisions, geographies, or product lines), or is otherwise completely dissimilar from what was certified, then the pre-certification would have no weight and could even count against the errant firm. ${ }^{318}$ Currently, prosecutors consider the effectiveness of a compliance program using vague high-level factors in the DOJ Prosecution Principles, which provide no real substantive guidance. ${ }^{319}$ The framework proposed above provides a more workable and objective solution.

Ideally, if a prosecutor cannot prove that the program was ineffective, he or she should not prosecute and the corporation should not pay any criminal fines or penalties. ${ }^{320}$ In other circumstances, depending on the nature and severity of the transgression, the firm may still be subject to penalties, remedial measures, and/or restitution, but would still not face criminal charges. ${ }^{321}$ This would minimize uncertainty, the minimal amount of credit given to firms for compliance programs, and the looming specter of prosecution regardless of good faith efforts to comply. ${ }^{322}$ In the event that the prosecutor still chooses to proceed, the court would rule on the issue pre-trial, assessing the reasonableness of the company's conduct by examining and weighing the factors. ${ }^{323}$ Although ideally this standard would replace the relatively vague standards in the Guidelines, it would still have no measureable effect if

314. H. Lowell Brown, The Corporate Director's Compliance Oversight Responsibility in the Post Caremark Era, 26 DEL. J. CoRP. 1, 139 (2001).

315. Arlen, supra note 136, at 62; see also, e.g., Johnson \& Johnson DPA, supra note 35 , at 31; Alliance One International, Inc. Non-Prosecution Agreement, at app. B (Aug. 6, 2010) [hereinafter Alliance One NPA].

316. See Ellen Podgor, Educating Compliance, 46 AM. CrIM. L. REV. 1523, 1530-31 (2009).

317. See Pamela H. Bucy, Corporate Criminal Liability: When Does It Make Sense?, 46 AM. CRIM. L. REV. 1437, 1447-52 (2009).

318. See, e.g., Johnson \& Johnson DPA, supra note 35, at 8-9; Alliance One NPA, supra note 315 , at 3 .

319. USAM, supra note 165 , ch. 9-28.800; see also FCPA Guide, supra note 53, at 56.

320. See Arlen, supra note 136, at 77-81.

321. See, e.g., supra note 225.

322. See supra notes 144,194 and accompanying text.

323. See supra text accompanying note 299. 
prosecutors were unwilling to consider these factors as a matter of law to constitute an affirmative defense. ${ }^{324}$

To provide optimal incentives for firms to develop appropriate compliance programs, the law must eliminate the final barrier-the fear that the information disclosed as part of a criminal investigation will be used against the firm in a civil action. ${ }^{325}$ An evidentiary privilege coupled with the availability of an affirmative defense will balance the scales and leave corporations with no reasonable justification to equivocate on disclosure when it is appropriate. ${ }^{326}$

An affirmative defense provides certainty for companies and rewards and encourages investment in state-of-the-art compliance programs. ${ }^{327}$ Further, companies will not be conflicted about their duty to self-disclose because doing so would only help the company. ${ }^{328}$ The company will know that an adequate, effective compliance program will lead to a decline in prosecution. $^{329}$

\section{CONCLUSION}

[There] is this abiding sense of unfairness as [liability] relates to the corporate criminal process.

...

... [I]f there is another way a corporate target can challenge the government, $I$ think that serves to have a moderating influence on a prosecutor who is either stupid, who is malevolent or who is a cowboy or cowgirl who just wants to try a case and not be reasonable.

...

... [1]f you really want to have a deterrence of corporate criminal liability, the best weapon against corporate misconduct is establishing an effective compliance program .... [W]hen you really think about it, when a corporation investigates itself, reports known violations, cooperates with the government . . . there really is

324. See supra notes 212,313 and accompanying text.

325. See supra text accompanying notes 219-20.

326. John S. Moot, Compliance Programs, Penalty Mitigation and the FERC, 29 ENERGY L.J. 547, 556-57 (2008).

327. See Podgor, supra note 51, at 1543.

328. Cf. Khanna, supra note 165 , at $1267-68$ ("In some cases involving strict liability, an evidentiary privilege protects corporations from information obtained in environmental audits being used against them. Such a privilege can overcome the issues associated with strict liability.").

329. See supra note 320 and accompanying text. 
no substantial federal interest in seeing that corporation prosecuted. $^{330}$

The current system of vicarious liability for the acts of even rogue employees who ignore clearly articulated policies leaves responsible companies in a quandary. Due to the disincentives of the current system, firms must decide if they should under-invest in cosmetic compliance programs thereby reducing the chance of detecting internal corporate wrongdoing or invest the appropriate resources into a state-of-the-art compliance program, but still risk a Dodd-Frank whistleblower bypassing their credible program and providing a potentially inaccurate tip to the SEC.

With the passage of Dodd-Frank, Congress should have taken the opportunity to reconsider the utility of the Guidelines in light of the most recent financial crisis. Tellingly, more than a few high ranking DOJ officials who formerly prosecuted corporations now decry the overcriminalization of corporate law and are calling for an affirmative defense. Rather than tweak the Guidelines, legislators can and should go further by providing an affirmative defense, using the FCPA as a pilot.

At the press conference announcing the Guide to the FCPA, Assistant Attorney General Lanny Breuer stated that an FCPA compliance defense would be "dangerous and antithetical to the way [the DOJ] pursues criminal justice cases ... [ [and that such a defense] runs the risk of a race to the bottom."331

The proposed affirmative defense outlined in this Article gives companies the incentive to implement a well-resourced, well-communicated compliance and anti-retaliation program that exceeds the standards in the current Guidelines. Companies that choose pre-certification and follow the dictates of the third-party auditor or government inspector should enjoy the benefit of the affirmative defense. Companies that choose not to expend the resources up front would be subject to the current system if they are charged with a crimemeaning that they would negotiate a DPA or an NPA with the government or go to trial.

After an appropriate time period, the defense should extend beyond the FCPA, perhaps to the antitrust arena where there is absolute criminal liability. An affirmative defense coupled with an evidentiary privilege will promote earlier detection and remedying of the wrongdoing, reduce government expenditures, provide more comfort to investors and regulators, allow the government to focus on companies without effective compliance programs, and, most importantly, provide incentives for companies to invest in robust compliance programs.

330. Thompson, supra note 147, at 1323, 1326-28.

331. The Guidance Press Conference, FCPA Professor (Nov. 15, 2012), http://www.fcpaprofessor.com/the-guidance-press-conference. 
Even with the option of the defense, many corporations will not want to bear the risk of a trial. But, at the very least, they will have a better negotiating position with prosecutors. Moreover, companies that attempt do the right thing will no longer be lumped into the same category as those who invest in the least expensive compliance programs or worse, engage in clearly intentional criminal behavior. If companies have the certainty that an affirmative defense is available, that certainty will invariably lead to stronger programs that can truly detect and prevent criminal acts from occurring in the future. 
90

Catholic University Law Review

[Vol. 62:41 